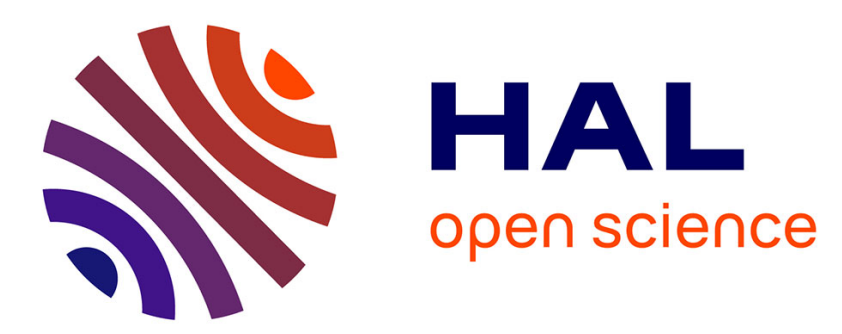

\title{
Global banking and the conduct of macroprudential policy in a monetary union \\ Jean-Christophe Poutineau, Gauthier Vermandel
}

\section{To cite this version:}

Jean-Christophe Poutineau, Gauthier Vermandel. Global banking and the conduct of macroprudential policy in a monetary union. Journal of Macroeconomics, 2018, 54 (B), pp.306-331. 10.1016/j.jmacro.2017.04.010 . halshs-01525396

\section{HAL Id: halshs-01525396 \\ https://shs.hal.science/halshs-01525396}

Submitted on 20 May 2017

HAL is a multi-disciplinary open access archive for the deposit and dissemination of scientific research documents, whether they are published or not. The documents may come from teaching and research institutions in France or abroad, or from public or private research centers.
L'archive ouverte pluridisciplinaire HAL, est destinée au dépôt et à la diffusion de documents scientifiques de niveau recherche, publiés ou non, émanant des établissements d'enseignement et de recherche français ou étrangers, des laboratoires publics ou privés. 
$\mathrm{H}$ ighlights

- W e estim ate a two-country $m$ odel $w$ ith intemationalbanking for the Euro A rea

- $\mathrm{W}$ e exam ine the role of cross-border lending on the reaction of capitalbu ers

- Targeting a national credit-to-G D P ratio should be favored to federal averages

- A federal targeting is destrable for a share of cross-border banking reaching $45 \%$

- Even w ith perfect banking integration, a national targeting rem ains optm al

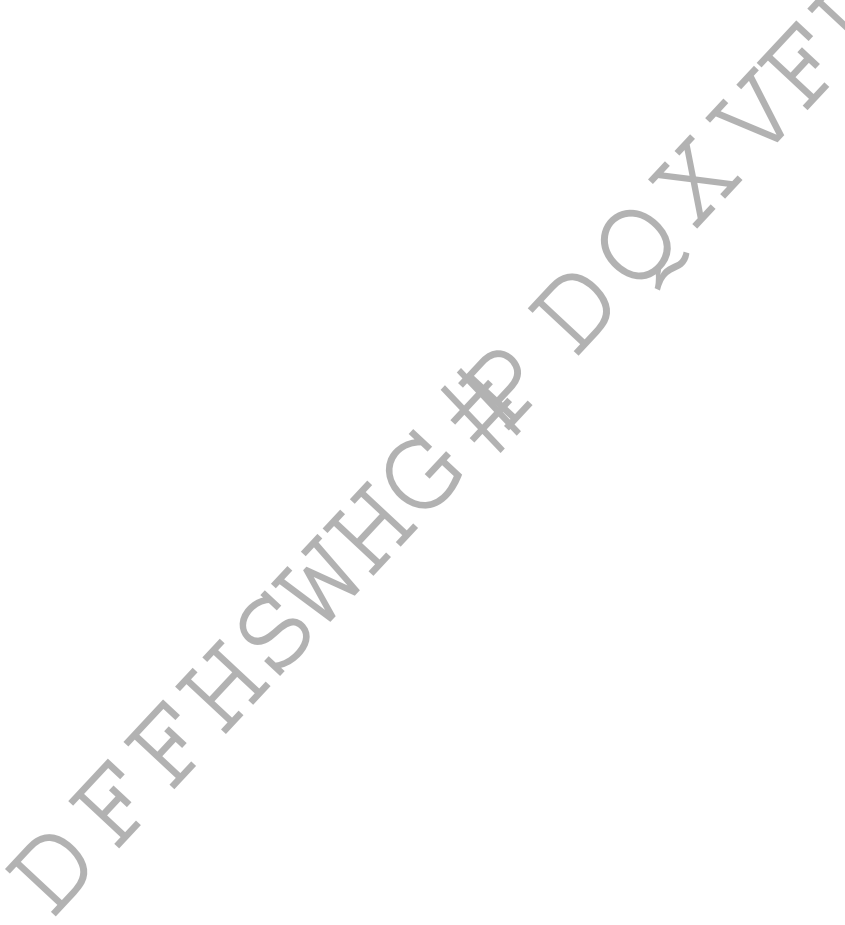




\section{Global Banking and the Conduct of Macroprudential Policy in a Monetary Union}

Jean-C hristophe Poutineau a , G authier Verm ande ${ }^{\mathrm{p}, \mathrm{c}, *}$

${ }^{a}$ CREM, UMR CNRS 6211, Université de Rennes I, 7 Place Hoche, 35065 Rennes Cedex, France. ${ }^{b}$ Paris-Dauphine University \& PSL Research University, Plaœ du Maréchal de Lattre de Tassigny, 75016 Paris, France.

'Franœ Stratégie, 18 Rue de Martignac, 75007 Paris.

\section{A bstract}

This paper questions the role of cross-border lending in the definition of national $\mathrm{m}$ acroprudentialpolicies in the European M onetary U nion. W ebuild and estim ate a two-country D SG E m odel w th conporate and interbank cross-border loans, Core-Periphery diverging financial cycles and a national im plem entation of coordinated m acropnudential m easures based on C ountercyclical Capital Bu ers. W e get three $m$ ain results. First, targeting a national credit-to-G D P ratio should be favored to federal averages as this nule induces better stabilizing perform ances in front of in portant divergences in credit cycles between core and peripheral countries. Second, policies reacting to the evolution of national credit supply should be favored as the transm ission channel of $\mathrm{m}$ acropnudential policy directly im pacts the m arginal cost of loan production and, by so, financial interm ediaries. Third, the interest of lifting up m acroprudential policym aking to the supra-national level rem ains questionable for adm issible value of intemational lending between Eurozone countries. Indeed, national capital bu ers reacting to the union-w ide loan-to-G D P ratio only lead to the sam e stabilization results than the one obtained under the national reaction if cross-border lending reaches $45 \%$. H ow ever, even if cross-border linkages are high enough to justify the im plem entation of a federal adjusted solution, the reaction to national lending conditions rem ains rem arkably optim al.

\footnotetext{
${ }^{*}$ Corresponding author

Email addresses: jean-christophe.poutineau@univ-rennes1.fr (Jean-Christ ophe Poutineau), gauthier@vermandel.fr (Gauthier Vermandel)
} 
Keywords: M acroprudential Policy, G lobal B anking, Intemational B usiness Cycles, Euro A rea

JEL classification: F42, F 45, E 58, F 34

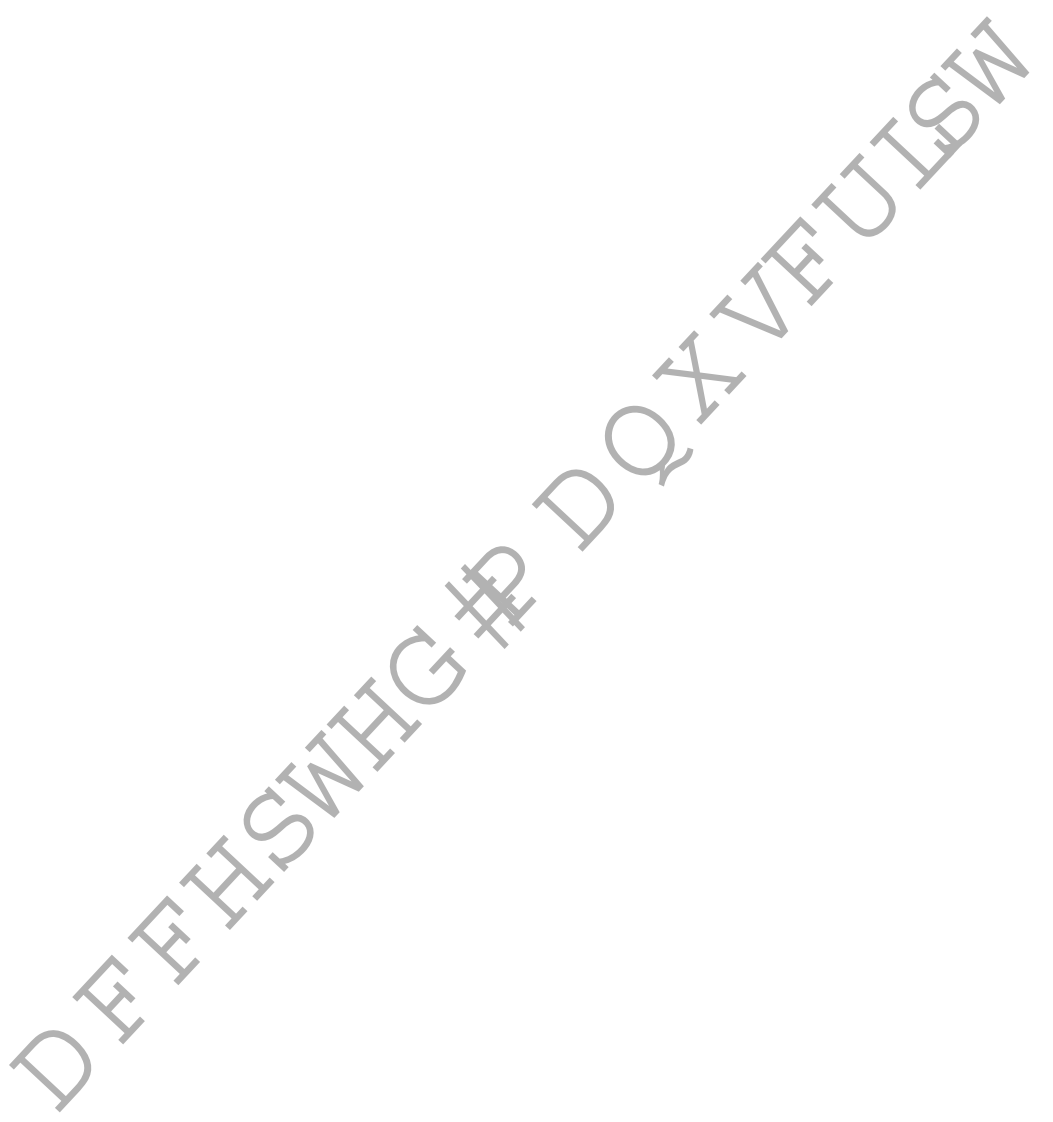




\section{Introduction}

The dismuption offinancial relations that follow ed the 2007 subprim e crisis set the basis for the adoption of $m$ acroprudential policies in m ost countries. ${ }^{1}$ In the Euro A rea, the im plem entation of such $m$ easures rem ains fragm ented along national lines while the coordination and intemalization of cross-border spillovers are achieved through the actions of the European System ic R isk B oard (ESR B , henceforth). This federal organization accounts for two conflicting features of the Eurozone that can be approached by contrasting core and peripheral countries. Panel (a) of $\mathrm{F}$ igure 1 show s that financial cycles (as m easured by the credit to GD P ratio in percentage deviation from H P trend) rem ain clearly national, which $m$ ilitates for a decentralized definition and im plem entation ofm acroprudentialm easures. $\mathrm{H}$ ow ever, as reported in panel (b) of $\mathrm{F}$ igure 1 , these tw o regions are closely linked by crosstborder banking activities (as $m$ easured by the share of bans lent to a foreign agent residing in another Euro A rea country) and the intemational spillovers of national m acroprudential policies $m$ ay be harm ful for the $m$ onetary union. The rem aining uncertainties on undesirable side-e ects of self oriented $m$ acropnudential policies have thus put global banks at a central stage in the on-going debate related to the conduct of $m$ acropnudential policies.

This paper questions how sizable cross-border lending flows should be treated in the definition of national $\mathrm{m}$ acropnudential policies in the Euro $\mathrm{A}$ rea. W e m ore particularly assess whether cross-border bank lending should explicitly be considered in the setting of coordinated national $m$ acroprudentialm easures or w hether national regulators should only focus on the sole national financial stance to contribute to the financial stability of the Eurozone

${ }^{1}$ In a nutshell, macroprudential policy aims at completing monetary policy to enhance the resilience of the financial system and contain the procyclicality of financial factors on activity.

${ }^{2}$ In the first group we aggregate data for countries with a current account surplus and low government bond yields over the sample period (Austria, Belgium, Germany, Finland, France, Luxembourg and Netherlands), while in the second group, we aggregate data for countries with a current account deficit and high government bond yields over the sample period (Spain, Greece, Ireland, Italy and Portugal).

${ }^{3}$ For example, regarding issues related to macroprudential policy with global banking, we refer to the IMF (2013, key issues, p31), the ESRB handbook (2014), ECB (2015, Financial Stability Review, May), Bank of England (2015, Staff Working Paper). 


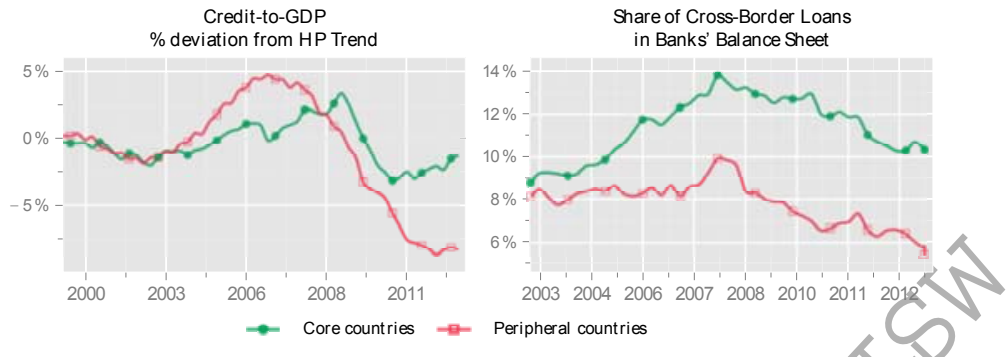

Not e: Cross-border lending refers to any financing arrangement that crosses national borders between a domestic bank and a foreign borrower. The share of cross-border loans is computed here as the ratio between loans to euro area excluding the domestic area and the loans to euro area (i.e. cross-border loans between core countries are included in the calculation of the share of international loans). Sources: ESRB and ECB statistics.

Figure 1: Stylized facts charact erizing the Eurosyst em banking syst em: credit cycles remain clearly national while cross-border lending experienced an important growth

W e build and estim ate a two-country D SG E m odel that accounts for two m ajor aspects to address the question at hands. First, we extend the setup of Poutineau and Verm andel (2015) - featuring cross-border banking on the comporate and interbank loan m arkets ${ }^{4}$ - to account for bank capital regulation and thus to contrast the e ectiveness of $m$ acropnudential policy from banking autarky to perfect integration. Second, in line w ith the actual organization of $m$ acropnudential policy, we focus on the joint-optim ization of m acropnudentialpolicy nules in each country using the countercyclicalcapitalbu er (C CB , henceforth) rate as an instrum ent. This solution has becom e one of the leading facets of prudential regulation since the adoption of B asel III accords (2010) by building up a bank capitalbu erduring periods of excessive credit grow th that can be released when system ic risks abate. The intemational dim ension of banks o ered by our setting allow s us to contrast di erent C CB rules based on: (i ) the federal or the national credit-to-gdp targeting,

\footnotetext{
${ }^{4}$ In this paper, we omit the mortgage market and concentrate on corporate and interbank loans. Given the insignificant size of cross-border housing loans in the portfolio of banks (the share of cross-border loans is below $1 \%$ in the Euro Area according to ECB internal data), this omission does not seem to be important for the analysis conducted here.

${ }^{5}$ We refer to Carboni et al. (2013) for a discussion regarding the macroprudential policy mandate in the Euro Area shared between European Central Bank and the Single Supervisory Mechanism, national compet ent authorities and coordinated by the European Systemic Risk Board.
} 
(ii ) the loan dem and (from firm s) or supply (from banks) to GD P targeting, and (iii) the loan inflow s-to-G D P ratio targeting as envisaged by R ey (2015).

The m ethodology em ployed in this paper com prises three steps. First, we build and estm ate a two-country D SG E m odel for the Euro A rea w ith only m onetary policy (as there are no observations for an estim ation of a m acroprudential nule). Second, we com pute the optim alpolicy rules (both $m$ onetary and $m$ acroprudential policy) given the estm ated param eters assum ing a two-stage gam e where m onetary policy is the leader 6 Third, we exam ine im plications of cross-border lending on the optim aldesign ofm acroprudential nules across country $m$ em bers of the Eurosystem using the optm al m onetary policy rule as a benchm ark.

The $m$ ain result of the paper suggests that self oriented m acroprudential national policies reacting to the evolution of hom e country loan creation, should be favored even w th high am ounts of cross-border lending flow s: F irst, targeting a national credit-to-gdp ratio should be favored to federal averages as this pule induces better stabilizing perform ances in front of im portant divergences in credit cycles between core and peripheral countries. Second, policies reacting to the evolution of national credit supply should be favored as the transm ission channel of $m$ acropnudential policy directly im pacts the m arginal cost of loan production and, by so, financial interm ediaries. Third, the interest of lifting up $m$ acroprudential policym aking to the supra-national level rem ains questionable for adm issible value of intemational lending betw een Eurozone countries. Indeed, national capital bu ers reacting to the union-w ide loan-to-G D P ratio only lead to the sam e stabilization results than the one obtained under the national reaction if cross-border lending reaches $45 \%$. H ow ever, even if cross-border linkages are high enough to justify the im plem entation of a federal adjusted solution, the reaction to national lending conditions rem ains rem arkably optimal.

A dditionally, we outline som e particularities regarding the conduct of m acroprudential

\footnotetext{
${ }^{6} \mathrm{~A}$ important branch of the literature analyzed the interaction between monetary policy and financial stability, a topic not covered in the paper as we concent rat e here on interactions between national prudential authorities. We refer to Woodford (2012) for a summary of policy challenges and results offered by the existing literature concerning the role of monetary policy in providing financial stability.
} 
policies for peripheral countries. W e find that adjusting the $m$ acroprudential instrum ent to capital inflow s-to-G D P is a prom ising tool for these countries that have experienced a large am ount of loan inflow s. Furtherm ore, disentangling the dem and/supply of credit has im plications for m acroprudential policym aking as it is preferable to target credit suppliers for core countries and borrow ers for peripheral econom ies.

O ur approach is partly related to a set of papers exam ining $m$ acroprudential m easures in the Eurozone w ith a closed econom y setup. Notably, D arraco-P ariès et 61 (2011) and Angeliniet al. (2014) build a D SG E m odelof the Eurozone close to G erefiet dy. (2010) w ith both conporate and housing credit $m$ arkets and evaluate the optim all $m$ ix betw een $m$ onetary and $m$ acroprudential policy using loss functions. A s a key contribution to the literature, they suggest that tim e-varying capital requirem ents can im prove $m$ acroeconom ic stability by supporting m onetary policy actions. O uranalysis can thus be considered as an extension to these papers, by accounting for the heterogeneity between Euro A rea participants and the existence of national $\mathrm{m}$ acroprudential policies $w$ ith/cross-border spillovers.

o ur paper also contributes to $m$ acroprudential policy analysis in open econom ies. As an exam ple, $Q$ uint and R abanal (2014) acoount for financial asym $m$ etries betw een participating countries and focus on the interaction betw een financial and housing cycles w thout considering crosstborder flow s between countries. By om itting cross-border lending, they naturally find that there are no important spillover e ects of regulation from one $m$ em ber state to another via an estim ated two-country D SG E m odel of the Eurozone. A dditionally, Jeanne (2014) em ploys a static open econom y m odel to evaluate the e ectiveness of m acroprudential and capital control $m$ easures. Contrary to $Q$ uint and R abanal (2014), he finds that these prudential policies generate im portant global spillovers even w ith intemational coordination.

The paper is organized as follow s: Section 2 describes the financial sector of the m odel. Section 3 takes the m odel to the data. Section 4 discusses the perform ance ofm acroprudentialpolicy. Section 5 provides a sensitivity analysis to assess the robustness of our results. Section 6 conchudes. 


\section{The financial sector}

The econom $y$ is com posed of two countries of unequal size and populated by households, firm $\mathrm{s}$ and banks. This first section describes the banking com ponent of the $\mathrm{m}$ odel while the rest of the fram ew ork (standard to the literature) is presented in appendix.

\subsection{The financial sector in a nutshell}

Figure 2 provides a broad picture of the financial sector and sum $m$ arizes its interaction $\mathrm{w}$ ith the rest of the econom $y$. B anks engage in interbank lending/borrow ing relations and provide corporate loans to entrepreneurs and deposit services to households. A uthorities a ect the decisions of the banking sector through m onetary and m acropnudentialpolicies.

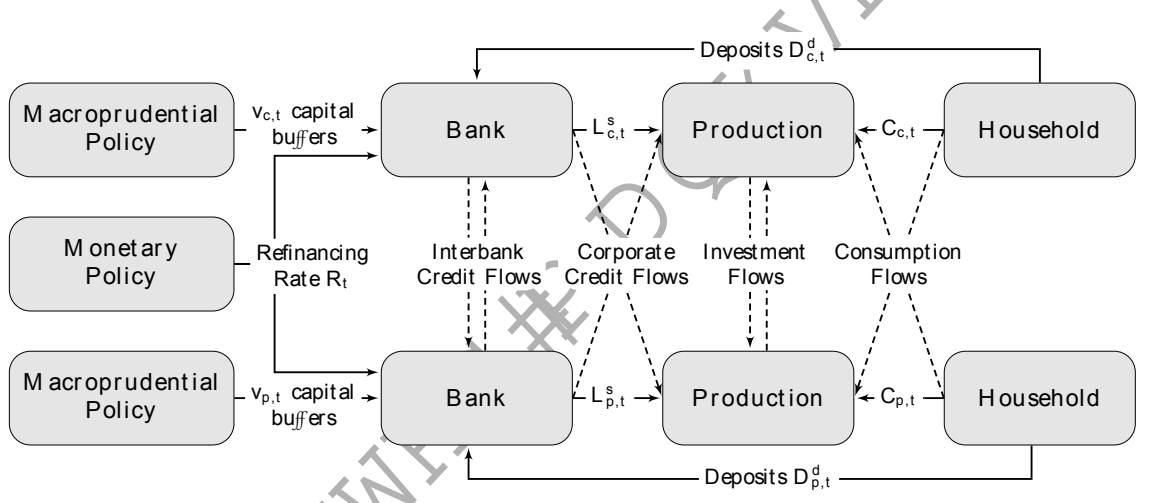

Figure 2: Macroprudential policy and cross-border banking in a New Keynesian Framework

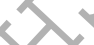

To introduce an interbank $m$ arket, we assum e that banks are heterogenous in term s of liquidity. This feature gives rise to an interbank $m$ arket where liquid banks provide interbank bans to both hom e and foreign banks. $T$ his feature is line $w$ ith the current European banking system characterized by banks relying on wholesale fundings as iךlustrated by $\mathrm{G}$ iannole et al. (2012). In our setup, the distinction betw een liquid and i7liquid banks lies in the direct access of liquid banks to ECB fundings which allow intra financial sector flows betw een financial interm ediaries. Extending this assum ption to an intemational perspec-

${ }^{7}$ This assumption is empirically motivated: in the Eurosystem, only a fraction of the 2500 banks par- 
tive, illiquid banks can bonrow from both dom estic and foreign liquid banks, which gives rise to cross-border interbank lending flow $\mathrm{s}$. The decision of the banking system regarding the provision of deposit services to households and loans to the conporate sector a ects the rest of the econom $y$ through the setting of deposit and lending interest rates. In line w ith the EM U situation, we do not consider cross-border deposit nor cross-border lending to households. The intemationalflow of bans between econom ies is thus a consequence of interbank liquidity provision and borrow ing choices undertaken by entrepreneurs frollow ing a com parison between the relative interest rates of dom estic and foreign conporate loans).

This paper adopts a m acroeconom ic perspective to focus on the ect of cross-border lending on the conduct of $m$ acroprudential policy in a heterogeneous m onetary union. As a consequence, the financial sector is com bined w ith a standard two-country D SG E m odel accounting for short run rigidities in goods prices and nom inal wages. In what follows, we outline the $m$ ain assum ptions regarding the functioning of the financial sector that are deem ed necessary to im prove both the tractability of the analysis and the estim ation of the $m$ any behavioral param eters of the D SG E structure. Som e m odelling choices have been done in line w ith the D SG E literature that contrast w ith a m ore standard description of the behavior of the banking sector as sum m arized by Freixas and R ochet (2008) and VanH oose (2009). As in the initial contribution of $\mathrm{G}$ erali et al. (2010), this $\mathrm{m}$ acro superstructure is augm ented w ith a highly sim plified banking m odel. A host of assum ptions should be invoked that e ectively splinter a bank's decisions into independent choices about di erent portions of its balande sheet.

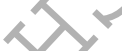

ticipates regularly to the bidding process in main refinancing operations of the ECB while the others rely on interbank funding.

${ }^{8}$ For tractability reasons we assume that even if banks differ in their ability to raise funds from the central bank, their loan and deposit supply decisions remain homogenous after aggregation. In a real life situation, illiquid banks may face more difficulties in attracting households deposits requiring banks to set higher deposit rates to compensate their default risk. Regarding corproate loans provision, the tighter funding constraint of illiquid may diminish their loan supply compared to liquid banks.

${ }^{9}$ First, portfolio separation holds (Baltensperger (1980) and Santomero (1984)), which means (Sealey and Lindley (1977) and Sealey (1985)) that a number of assumptions have been invoked. For instance, either shareholder unanimity is assumed for all banks in the model, or risk neutrality has been assumed to render shareholder unanimity a non-issue. In addition, it must be assumed that banks' costs of real resources utilized in their operations are separable from resource costs for others of the banks' assets and liabilities at during each period and across periods if interperiod adjustment costs are taken into account. Finally, banks must have access to a market in which they can both borrow and lend at exactly the same 
This paper extends Poutineau and Verm andel (2015) to account for deposit decisions and for $\mathrm{m}$ acropnudential consideration in the balance sheets of financial interm ediaries. The stidkiness in both deposit and loan interest rates is a key ingredient of the fram ework. The setting of interest rate $m$ im ics the way other stidky nom inal variables such as prices and wages are set in the model by adopting a Calvo-type m echanism . This device, shared by $\mathrm{m}$ ost D SG E m odels w ith a banking sector, partly contrasts w th the literature developed from the banking industry perspective. Indeed, m ost of the banking iterature has, follow ing Flannery (1982) original work on deposits as quasifixêd factors, focused on intertem poral quantity adjustm ent costs. It is also worth noting that the substantial banking literature on this topic has proposed altemative w ays of approaching this question, including Cosim ano and Van Huyck (1989), Cosim ano (1987, 1988), and Elyasiani et al. (1995) and Abo-Zaid (2015). Furtherm ore, shuggish and even asym m etric variations in bank retail rates have been docum ented in the em pirical literature as in Van Leuvensteijn et al. (2013) through im perfect com petition am ong banking system s, while Kopedky and Van H oose (2012) rely on intertem poral quantity adjustm ent costs together w ith im perfect com petition to explain such observations. The adoption of a Calvo m echanism com bined $\mathrm{w}$ ith $\mathrm{m}$ onopolistic com petition has been em ployed here in a $\mathrm{m}$ acro-perspective for credit and deposit interest rates, as this solution allows us to consider the shuggishness in the adjustm ent of all the nom inal variables of the econom y (prices, wages and interest rates) through the estim ation of a "C alvo lottery param eter".

As a second m ajornoticeable di erence from Poutineau and Verm andel (2015), we account for endogenous leverage offinancial interm ediaries, thus reflecting the riskiness in the balance sheet of banks. W e use tim e-varying capital requirem ents as the $m$ acroprudential instrum ent. A sunderlined by A ngeliniet al. (2014), capitalbu ers have taken a center stage in the ongoing debate on regulatory reform and have becom e one of leading facet ofm acroprudential regulation. Specifically in the European U nion, a num ber of m acro-prudential policy instrum ents including countercyclical bu ers are em bedded in the legislative texts 
transposing the B asel III regulatory standards into EU law..$^{10}$ To account for this com pulsory $m$ acroprudential instrum ent, we borrow the m odelling devioe of $D$ arraco-P ariès et al. (2011) and Angeliniet al. (2014) by assum ing that each type ofbank m ust pay a quadratic cost when its risk weighted assets ratio deviates from the tim e-varying ratio fixed by the $m$ acroprudential authority in country $i$ according to the system ic risk arising $w$ thin the financial system. The decision to penalize banks for keeping equity-capital positions below the o cialbenchm ark is easy to understand, as undercapitalized banks m ake the banking sector m ore fragile and in tum subject to bank nuns (D iam ond and R fjan (2001)). Sym $m$ etrically, the decision to im pose costs on banks for having equity-capital positions above the required levels $\mathrm{m}$ ay be understood in a m acroeconom ic perspective: by keeping $\mathrm{m}$ ore equity capital levels than required by the 0 cial regulation, the banking sector diverts resources and, in tum, creates credit rationing for both entrepreneurs and illiquid banks. This $m$ ay create lower than desired banking activify, reduce investm ent in the econom $y$ and incur ine ciencies. ${ }^{11}$

\subsection{Interbank relations}

In each country the banking system consists of two distinct branches: a continuum of m onopolistic banks and financial packers. M onopolistic banks provide di erent types of bans and deposit services and set interest rates on a C alvo basis. Thefinancialinterm ediary is a CES packer that produces one hom ogenous loan and deposit service. ${ }^{12}$ A share $\lambda$ of

${ }^{10}$ Namely the new Capital Requirements Directive (CRD IV) and the Capital Requirements Regulation (CRR). We refer to Carboni et al. (2013) for a discussion regarding the macroprudential policy mandate in the Euro Area shared between ECB/ SSM, national competent authorities and coordinated by the ESRB.

${ }^{11}$ Van den heuvel (2008) finds using a general equilibrium model that increasing capital requirements induces high welfare costs in terms of unconditional consumption, suggesting that capital requirements should be lower than in the current adequacy framework. Clerc et al. (2015) highlight the presence of a tradeoff using a financial accelerat or model between too high and too low capital requirements.

12The financial packer acts as a loan and deposit bundler in a perfectly competitive market. Banks supply differentiated types b of deposits $D_{i, t}(b)$ and loans $L_{i, t}^{s}$ (b) bundled by financial packers. Their packing technology for deposit services and loans reads as, $D_{i, t}^{d}=\left[\left(1 / n_{i}\right)^{1 / D} G\left(D_{i, t}(b)^{(D-1) / D}\right)\right]^{D /(D-1)}$, and $L_{i, t}^{d}=$ $\left[\left(1 / n_{i}\right)^{1 / L} G\left(L_{i, t}^{s}(b)^{(L-1) / L}\right)\right]^{L /(L-1)}$. It maximizes profits, $R_{i, t}^{D} D_{i, t}^{d}+R_{i, t}^{L} L_{i, t}^{d}-G\left(R_{i, t}^{D}(b) D_{i, t}(b)\right)-$ $G\left(R_{i, t}^{L}(b) L_{i, t}^{s}(b)\right)$, subject to their two technology curves. Here, $L_{i, t}^{d}$ is the loans demand from home and foreign entrepreneurs, $D_{i, t}^{d}$ is the deposit services demand from domestic households and $G($.$) is$ the aggregator function. Deposits and loans are imperfect substitute with elasticity of substitution $\mathrm{D}<-1$ and $L>1$. The corresponding demand functions associated from the previous problem are, $D_{i, t}(b)=\left(1 / n_{i}\right)\left(R_{i, t}^{D}(b) / R_{i, t}^{D}\right)^{-} D D_{i, t}^{d}$ and $L_{i, t}^{s}(b)=\left(1 / n_{i}\right)\left(R_{i, t}^{L}(b) / R_{i, t}^{L}\right)^{-} L L_{i, t}^{d}$. The aggre- 
banks is illiquid (i.e. credit constrained), while the rem aining share of banks $1 \lambda$ is liquid and supplies interbank loans to illiquid banks.

The representative share $\lambda$ of illiquid banks $b$ in country $i$ has the follow ing balance sheet,

$$
L_{i, t}^{s}=I B_{i, t}^{H}+B K_{i, t}^{i \prime \prime}+D_{i, t}+l i a b_{i, t}^{\prime \prime},
$$

where $L_{i, t}^{s}$ is the loan supply of borrow ing banks, I $B_{i, t}^{H}$ is the interbank loans supplied by liquid banks subject to extemal habits, $B K_{i, t}^{i l l}$ is the bank capital, $D_{i, t}$ are deposit services to households and liab, are other liabilities in the balance sheet of the bank that are not considered in the model ${ }^{13}$ To close the model, we assum e that the cost of these liabilities is set by the central bank through its refinancing rate. W e suppose that the dem and for interbank finds are subject to extemal habits at a degree $h_{i}^{B}$ where $I B_{i, t}^{H}=I B_{i, t}^{d}-h_{i}^{B}\left(I B_{i, t-1}^{d}-\overline{I B}_{i}^{d}\right)$. These habits captures the em pirical autocomelation of interbank funding. In addition, these habits are em pirically docum ented in the interbank network literature: Finger et al. $(2014,2015)$ find at a bank level that bilateral links betw een banks are persistent as banks heavily rely on wellestablished business relations, thus exhibiting som e habits in borrowing/lending decisions.

The one-period stream of profits of the $b$-th illiquid bank is given by

$$
\begin{aligned}
& i, i l l=1-\mu^{B}\left(1-E_{t}\left\{n_{i, t+1}\right\}\right) \quad 1+R_{i, t}^{L} L_{i, t}^{s}-1+R_{i, t}^{D} D_{i, t}-1+P_{i, t}^{l B} I B_{i, t}^{H}
\end{aligned}
$$

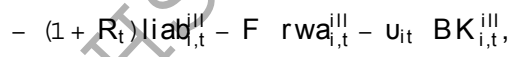

where $\left.\mu^{\mathrm{B}} \quad 0,1\right]$ denotes the loss-given-default (i.e. the percentage of the am ount ow ed on a defaulted loan that the bank is not able to recover), $1-E_{t}\left\{\eta_{i, t+1}\right\}$ is the expected gate price index of all varieties in the econon

gate price index of all varieties in the economy is given by, $\left.R_{i, t}^{D}=\left[\left(1 / n_{i}\right) G\left(R_{i, t}^{D}(b)^{1-} D\right)\right]^{1 /(1-} D\right)$ and $\mathrm{R}_{\mathrm{i}, \mathrm{t}}^{\mathrm{L}}=\left[\left(1 / \mathrm{n}_{\mathrm{i}}\right) \mathrm{G}\left(\mathrm{R}_{\mathrm{i}, \mathrm{t}}^{\mathrm{L}}(\mathrm{b})^{1-} \mathrm{L}\right)\right]^{1 /(1-L)}$.

${ }^{13}$ We suppose that they follow an exogenous $A R(1)$ shock process $\varepsilon_{i, t}^{B}$ such that, liab ${ }_{1, t}=e^{\varepsilon_{i, t}^{B}} \overline{\Gamma i a b}$, this shock captures some aggregate movements in the funding constraint araising from the wholesale funding market, see for instance Pérignon et al. (2017) for an analysis of liquidity runs on the French unsecured market of certificates of deposits. 
average default rate of the bank's hom e and foreign custom ers, ${ }_{i, t}^{14}$ is deposit rate, $P_{i, t}^{1 B}$ is the bomrow ing cost on the interbank, $\mathrm{R}_{\mathrm{t}}$ the interest rate set by the central bank and $F_{i}(\cdot)$ denotes the capital requirem ent cost function. This cost function is taken from G erali et al. (2010) and is defined as $F_{i}(x)=0.5 X^{k} x^{2}$ where $X^{k} \quad 0$ is the cost of capital adequacy fram ew ork paid in term ofbank capital ${ }^{15}$ This cost function is a shortcut that $m$ akes bank capital m ore costly than any source of financing, and allow $s$ in tum to $m$ im ic the response of credit rates and credit to a capital requirem ent tightening consistently with em pirical evidence (see for instance Fraisse et al. (2013) for an em pirical m easure of this elasticity). $\mathrm{W}$ hen the bank capital-to-risky-asset ratio $\mathrm{rwa}_{\mathrm{i}, \mathrm{t}}^{\mathrm{ill}}$ is below the policy target $\mathrm{u}_{\mathrm{it}}$, the bank is penalized by regulatory nules that a ect the borrow ing rates in the monetary union and in tum dam age output. Thispenalization replicates them arket discipline in posed by investors on low capitalized banks, forcing the latter to boost their retained eamings though higher credit rates. The risk is evaluated through fixed w eights on assets, based on the type of the borrow ers (1 for comporate exposure and 020 for interbank exposure betw een O E CD banks as defined in Basel accords) as defined in Basel I accords. Since illiquid banks are only exposed to comporate risk, the risk weighted assets ratio is given by $\mathrm{rwa}_{\mathrm{i}, \mathrm{t}}^{\mathrm{ill}}=\mathrm{BK}_{\mathrm{i}, \mathrm{t}}^{\mathrm{ill}} / \mathrm{L}_{\mathrm{i}, \mathrm{t}}^{\mathrm{s}}$. In addition, the financial interm ediary has access to dom estic and foreign interbank loans to $\mathrm{m}$ eet its balance sheet. The m odelling device to introduce intemational borrow ing is analogous to trade channels through a CES as in Poutineau and Verm andel (2015) and B rzoza-B rzezina et al, (2015). The total am ount borrow ed by the representative bank reads as follow s:

$$
I B_{i, t}^{d}=\lambda^{1-\alpha_{i}^{I B} 1 / \xi}\left|B_{h i, t}^{d}(\xi-1) / \xi+\alpha_{i}^{\mid B} 1 / \xi\right| B_{f i, t}^{d}(\xi-1) / \xi \xi /(\xi-1),
$$

where param eter $\xi>0$ is the elasticity of substitution betw een dom estic and foreign in-

${ }^{4}$ To simplify both the steady state and the log-linear version of the model, the bank default expectation regarding entrepreneurs' projects is defined by a geometric average of home and foreign surviving rates of entrepreneurs, $\eta_{i, t}=\left(\eta_{h, t}^{E}\right)^{1-\alpha_{h}^{L}}\left(\eta_{f, t}^{E}\right)^{\alpha_{j}^{L}} \bar{\eta}^{\alpha_{h}^{L}-\alpha_{j}^{L}}$ where $\eta_{i, t+1}^{E}$ is the default rate of entrepreneurs operating in country $i \quad\{c, p\}$. The expression $\bar{\eta}^{\alpha_{h}^{L}-a_{j}^{L}}$ ensures the detesministic steady state remains symmetric between Core and Periphery without affecting the dynamic of the model up to a first order approximation.

${ }^{15}$ The quadratic nature of this cost has been discussed in the previous subsection. 
terbank funds, $\alpha_{i}^{\mathrm{B}}$ represents the percentage of cross-border interbank ban flow $\mathrm{s}$ in the $m$ onetary union and I $B_{h i, t+1}^{d}$ (resp. I $B_{f i, t+1}^{d}$ ) the am ount of dom estic (resp. foreign) loans dem anded by bonrow ing bank $b$ in country $i$. This existence of an hom e bias on the interbank $m$ arket is em pirically $m$ otivated, Fricke and Lux (2015) find, using Italian bank-level data, that Italian banks tend to trade $w$ ith each other rather than $w$ ith foreign banks, in particular after the financial turm oil. M ore broadly in the literature of finance, the hom $e$ bias in portfolio was first docum ented by French and Poterba (1991).

The total cost incurred by illiquid banks to finance interbank bans, $1+P_{i, t}^{M}$, is thus defined according to the CES aggregator:

$$
1+P_{i, t}^{l B}=\left(1-\alpha_{i}^{l B} \quad\left(1+R_{h, t}^{l B}\right)^{1-\xi}+\alpha_{i}^{I B}\left(1+R_{f, t}^{I B}\right)^{1-\xi}\right)^{1 /(1-\xi)},
$$

where $1+R_{h, t}^{1 B}$ (resp. $1+R_{f, t}^{1 B}$ ) is the cost of loans obtained from hom e (resp. foreign) banks in country $\mathrm{i}$. F inally follow ing $\mathrm{G}$ erali et al. (2010), the bank capital accum ulation process of illiquid banks $\left(B K_{i, t}^{i l l}\right)$ is determ ined by:

$$
B K_{i, t}^{i l l}=1-\delta_{i}^{i l l} \quad \stackrel{i l l}{i, t-1},
$$

where $\phi_{i}^{\prime \prime} \quad[0,1] \mathrm{m}$ easures resources used in m anaging bank capital and conducting the overallbanking interm ediation activity and is determ ined endogenously by the steady state of the $\mathrm{m}$ odel $\mathrm{G}$ iven the functional form of $\mathrm{F}_{\mathrm{i}}(\cdot)$, the first order condition on loans which determ ines the $m$ arginal cost of supplying an additional unit of loans to hom e and foreign entrepreneurs is:

$$
1+M C_{i, t}^{i l l}=\frac{1+P_{i, t}^{l B}+X^{k} U_{i t}-r w a_{i, t}^{i l l} r w a_{i, t}^{i l l}{ }^{2}}{1-\mu^{B}\left(1-E_{t}\left\{\eta_{i, t+1}\right\}\right)} .
$$

From this equation, we observe that an increase (reduction) in the $\mathrm{CCB}$ rate $\mathrm{U}_{\mathrm{i}, \mathrm{t}}$ (risk weighted assets ratio $r$ wai,t $a_{i, l}^{i l}$ in poses on banks to accum ulate m ore equity via retained eamings through a rise in credit rates. Param eter $X^{k}$ determ ines the elasticity of interest 
rates to capital regulation change. ${ }^{16}$ D uring phases of expansion, banks have incentives to increase their leverage aw ay from the target in order to boost their profits. This risk taking by banks is addressed in our m odel though the cost function that forces banks to control their capital structure.

The fraction $1-\lambda$ of rem aining liquid banks has the follow ing balance sheet:

$$
L_{i, t}^{s}+I B_{i, t}^{s}=L_{i, t}^{E C B}+B K_{i, t}^{l i q}+D_{i, t}+l i a b_{, t}^{l i q},
$$

where $L_{i, t}^{s}$ is the lending supply to entrepreneurs, I $B_{i, t}^{s}$ is the supply of funds on the interbank $m$ arket, $L_{i, t}^{E C B}$ is the am ount of refinancing operations obtained by the liquid bank, $B K_{i, t}^{\text {liq }}$ is the am ount of bank capital, $D_{i, t}$ are deposits collected from dom estic households and liab,$t$ are exogenous liabilities as explained previously. The one-period profit of the bank $\operatorname{liq}_{i, t}$ is defined as:

$$
\begin{aligned}
\operatorname{liq}_{i, t} & =1-\mu^{B}\left(1-E_{t}\left\{\eta_{i, t+1}\right\}\right) \quad 1+R_{i, t}^{L} L_{i, t}^{s}+1+R_{i, t}^{l B} I B_{i, t}^{s}-1+R_{i, t}^{D} D_{i, t} \quad \text { (8) } \\
& -\left(1+R_{t}\right) l i a b_{i, t}^{l i q}-\left(1+R_{t}\right) L_{i, t}^{E C B}-F\left(r w a_{i, t}^{l i q}-U_{i t}\right) B K_{i, t}^{l i q} .
\end{aligned}
$$

Here, $R_{i, t}^{1 B}$ is the interest rate set by liquid banks to hom e and foreign illiquid banks, $R_{t}$ is the refinancing rate of the central bank and $F_{i}(\cdot)$ denotes the sam e B asel cost function as for iliquid banks: $F_{i}(X)=0,5 X^{k} X^{2}$. Interbank clain s a ect the am ount of equity held by banks and are given a risk weight at $20 \%$. The risk weighted asset ratio for liquid bank inconporating conporate and bank exposures is given by $\mathrm{rwa}_{\mathrm{i}, \mathrm{t}}^{\mathrm{liq}}=\mathrm{BK}_{\mathrm{i}, \mathrm{t}}^{\mathrm{liq}} /\left(\mathrm{L}_{\mathrm{i}, \mathrm{t}}^{\mathrm{s}}+0.2 \mathrm{~B} \mathrm{~B}_{\mathrm{i}, \mathrm{t}}^{\mathrm{s}}\right)$. A ccording to the iniquid bank, bank capital of liquid banks evolves according to

$$
B K_{i, t}^{\operatorname{liq}}=\left(1-T_{i}^{l i q}\right) \underset{i, t}{\operatorname{liq}}
$$

where $\delta_{1}^{\text {liq }}[0,1]$ is sim ilar to the illiquid bank and m easures the fraction of capital used during the interm ediation process that cannot be re-invested next period. The first order

\footnotetext{
${ }^{16}$ Empirically, Fraisse et al. (2013) find at a bank level that one percentage increase in capital requirements leads to a reduction in lending by approximately $10 \%$.
} 
condition on loans determ ining the $m$ arginal cost of loans of the liquid bank $b$ is:

$$
1+M C_{i, t}^{i l l}=\frac{1+P_{i, t}^{I B}+X^{k} u_{i t}-r w a_{i, t}^{i l l} r w a_{i, t}^{i l l}{ }^{2}}{1-\mu^{b}\left(1-E_{t}\left\{\eta_{i, t+1}\right\}\right)}
$$

and the second first order condition on interbank loans determ ines the interbank rate set by banks operating in country $\mathrm{i}$ :

$$
R_{i, t}^{l B}=R_{t}+0.2 X^{k}\left(U_{i t}-r w a_{i, t}^{l i q}\right)\left(r w a_{i, t}^{l i q}\right)^{2} .
$$

H ere again, an increase in bank capital requirem ents raises the bank's cost of lending, and in tum increases both interbank and comporate interest rates, $T$ his result is consistent w ith standard business cycle m odels and is referred to the bank capital channel as in Van den Heuvel (2008), M eh and M oran (2010), D arraco-Pariès et, (2011) and A ngelini et al. (2014).

\subsection{Interest rate setting}

W e assum e that interest rates on deposits and corporate credit loans are sticky. In particular, shuggish and even asym m etric variations in bank retail rates have been docum ented in the em pirical literature as in K Gpedy and Van H oose (2012) and Van Leuvensteijn et al. (2013) through im perfect com petition am ong banking system s. The setting of interest rate $\mathrm{m}$ in ics the way other stidxy nom inal variables such as prices and wages are set in the m odel. A s in D angacor-Pariès et al. (2011), we introduce a Calvo m odel for credit rates to firm s and deposit rates while the interbank rate is left flexible as banks operate under perfect com petition on the interbank m arket. Banks m ust solve a two-stage problem. In the first stage, banks $m$ inim ize the cost of $m$ anaging their funds on a com petitive input $m$ arkets by com puting the $m$ arginal cost of supplying an additional ban to borrow ers and a deposit service to households. The com putation of these m arginal costs has already been perform ed in the previous subsection. In a second stage, they operate under m onopolistic com petition by applying a $m$ arkup ( $m$ arkdow $n$ ) on their com m ercial loan (deposit) rate, and set the interest rate on a staggered basis. U sing a Calvo nom inal rigidity devide, each period a random fraction $\theta_{i}^{L} \quad\left(\theta_{i}^{D}\right)$ of banks is unable to update its lending (deposit) rate, 
$R_{i, t}^{L}=R_{i, t-1}^{L}\left(R_{i, t}^{D}=R_{i, t-1}^{D}\right)$, creating an im perfect transm ission of m onetary policy decisions to borrowers and savers living in the m onetary union. The bank that it is able to m odify its ban interest rate ( $w$ th a constant probability $1-\theta_{i}^{L}$ ) chooses $R_{i, t}^{L, *}$ to $m$ axim ize its expected stream of profits adjusted by the risk of default:

$$
E_{t}^{X}{ }_{s=0}^{X} \theta_{i}^{L}{ }^{\top} \quad i_{i, t+s} 1-\mu^{B}\left(1-\eta_{i, t+1+\tau}\right) \quad R_{i, t}^{L+*}-\exp \left(\varepsilon_{i, t+s}^{L}\right) M C_{i, t+s}^{L} L_{i, t+s}^{s}, \quad(12)
$$

where $\varepsilon_{i, t}^{L}$ is an ad-hoc m arkup AR (1) shock to the credit rate equation, $\theta_{i}^{L} \quad[0,1)$ is the Calvo lattery coe cient determ ining the degree of nom inal rigidity and $M C_{i, t}^{L}$ is the aggregate m arginal cost com bining outputs from liquid and illiquid banks of country i . W e aggregate loans from liquid and illiquid banks and their respective $m$ arginal costs before applying the $m$ arkup for tractability punposes: this device is useful to com pute a single Phillips curve as well as an unique credit rate for both liquid and illiquid banks. We borrow this shortcut procedure from G erali et al. (2010) adapted in a di erent context, i.e. all banks belonging to a national banking system share the sam e m arginal cost of production, reflecting the average liquidity degree of national banks: $1+M_{i, t}^{L}=(1+$ $\left.M C_{i, t}^{i l l}\right)^{\lambda}\left(1+M C_{i, t}^{l i q}\right)^{(1-\lambda)}$. In addition the banking spread reflecting the level of financial distress is given by $S_{i, t}^{L}=\left(1+R_{i, t}^{L}\right) /\left(1+R_{t}\right)$.

In a sim ilar fashion for deposit rates, assum ing that it is able to $\mathrm{m}$ odify its interest rate $w$ ith a constant probability $1-\theta_{i}^{\mathrm{D}}$, the representative bank chooses $R_{i, t}^{\mathrm{D} *}$ to $m$ axim ize its expected stream of profits, by applying a $\mathrm{m}$ arkdown on the refinancing rate of the central bank $R_{t}$ :

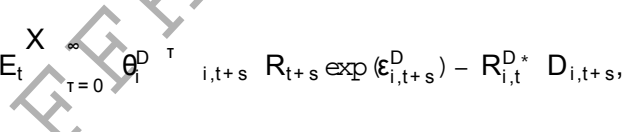

where $\varepsilon_{i, t}^{D}$ is an ad-hoc tim e-varying $A R(1) m$ arkdown shodk to the deposit rate equation and $\theta_{1}^{D} \quad[0,1)$ is the Calvo lottery param eter.

\subsection{Macroprudential policy}

M acroprudential policy a ects the general equilibrium of the econom $y$ through the policy instrum ent $v_{i, t}$ that contributes to the $m$ arginal cost of com m ercial banks' loans. 
A s a consequence, a m acroprudential policy tightening is associated $w$ ith higher lending rates, and low er bank credit grow th and asset prices. W e assum e that the $m$ acroprudential authority sets the tim e-varying capital requirem ent $\mathrm{v}_{\mathrm{i}, \mathrm{t}}$ according to:

$$
v_{i, t}=\left(1-\rho_{i}^{v}\right) \nabla+\rho_{i}^{v} v_{i, t-1}+\varphi_{i}\left(T_{i, t}-\overline{T_{i}}\right),
$$

where $\rho_{i}^{v} \quad[0,1)$ is the sm oothing coe cient of the rule, $T_{i, t}$ is the $m$ acroprudential target, $\varphi_{i} \quad 0$ is the $m$ acropnudential weight to the target in country $i$ and $\bar{T}_{i}$ is the steady state of the target. In our specification, capital requirem ents are expected to increase when the target deviates from its steady state. The choice of the target $\mathrm{T}_{\mathrm{i}, \mathrm{t}}$ is a key aspect of the paper that will be discussed below .

The ESR B has developed a bu erguide to choose the C CB rate based on the credit-togdp gap..$^{17}$ H ow ever, the global nature of the European banking system introduces m any possibilities for the definition of the credit-to-gdp ratio taken into account by national authorities. Indeed, the CCB rate m ay be adjusted to the credit supply (of banks) or the credit dem and (of entrepreneurs), 18 either on a national or on a federal basis. O ur fram ew ork w ith intemational bank flow s allow s us to distinguish betw een five operational targets as listed in Table 1.

The first set of credit targeting nules is oriented tow ards the supply of credit using either a federal (1 a) or a country-specific aggregate (1 b). A m acroprudential policy based on credit supply aim s at stabilizing lenders by focusing m ore on the stabilization of financial shocks hitting lenders rather than dem and and supply shodks hitting borrow ers. G iven the scale of crosstoorder loans in the Eurozone, the decisions of the national supervisor has side e ects on gountries where a national bank has a subsidiary or branches or where this bank lends to $m$ ay favor a federal definition of the rati. Thus to handle these pecuniary

${ }^{7}$ Other indicators (such as early warning variables) are included in the CCB guide which are not imple mentable in our model.

${ }^{18}$ In an open economy context where banks can lend across borders, banks supply credit to both home and foreign, which creates a gap between the domestic supply and the domestic demand for loans. This distinction between demand and supply is easy to see on the market clearing conditions of interbank (Equation B.23) and corporate markets (B.22). 
Table 1

Various Macroprudential Policy Schemes in terms of Target (average in the monetary union, national supply or national target) and in terms of policy stance (common or national-adjusted)

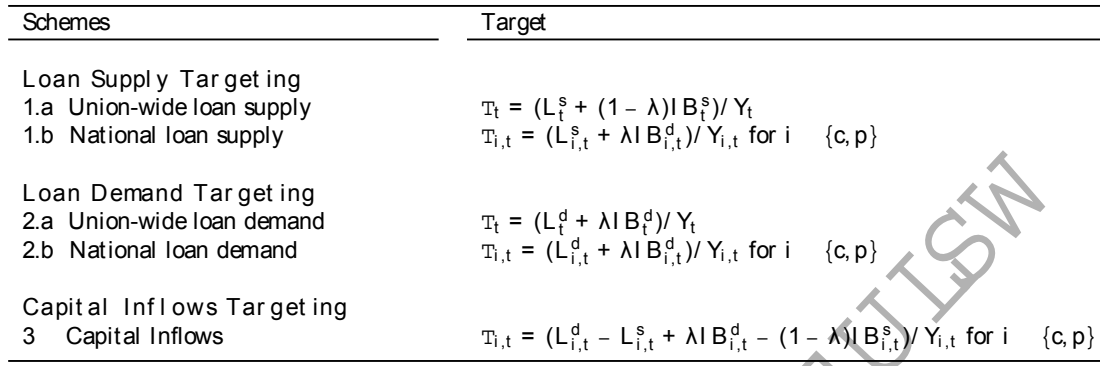

Note: variables without country subscript such as $x_{t}$ denote union-wide averages comput ed as a weighted sum of each count ry $x_{t}=n x_{c, t}+(1-n) x_{p, t}$.

extemalities, we evaluate the possibility of an union-wide targeting system (1 a) against a national targeting system ( $1 \mathrm{~b})$, the latter being expected to create $m$ ore extemalities (positive or negative) as it a ects the foreign banking system w ithout taking into account its financial developm ents. ${ }^{19}$

The second set of credit targeting nules concentrates on the dem and of credit em anating from entrepreneurs. ${ }^{20}$ The interest of a CCB rate taibred to borrowers is that it $m$ ay provide m ore stabilization follow ing real and nom inal shocks hitting households and firm s at the expense of financial shodks a ecting banks. This solution seeks at intemalizing the social cost of entrepreneurs' over-borrow ing that $m$ ay arise given their biased expectations. As this policy regim e ine ciently a ects foreign borrowers through crosstborder lending, spillovers e ects m ay be dam pened by a federal targeting (2 a) rather than a national one (2 b) .

W e also evaluate the interest of adopting provisional m easures to a ect cross border lending directly, through targeting capital inflow s in the C CB . This solution, as envisaged

For further discussions of these cross-border issues, we refer to Beck et al. (2016).

${ }^{20} \mathrm{~A}$ loan demand targeting is feasible in a real life situation, the ECB already disentangles the credit demand and supply by collecting the domestic and cross-border positions of Euro area monetary financial institutions since 1999 for each participant of the monetary union. Regarding the demand side of credit markets, the bank lending survey published by the ECB on a quarterly basis provides an analysis of the driving forces of the demand of credit in the Euro Area. For the supply side, both the ECB and the BIS collect domestic and cross-border positions of euro area monetary financial institutions. 
by Jeanne and Korinek (2010), B runnerm eier et al. (2012) and Rey (2015), is relatively sim ilar to a capital control $m$ easure. The $m$ ain insight behind this schem e would rely on the fact that persistent capital account im balances induce financial stability risks and $m$ ay have im plications for the sustainability of net extemal asset positions. In particular since the creation in the Eurozone, global banking has experienced an explosive grow th helping to fiel unsustainable credit boom s in peripheraleconom ies such as in Spain and in Ireland, follow ed by a sudden stop in capital inflow s com pensated by unconventional m easures. M acroprudentialpolicies can play a key role to contain this problem by im posing targeted regulations on banks engaged in cross-border activities. W hen bonrow ing to other European banks is increasing faster $\mathrm{w}$ ith respect to the $\mathrm{GD}$ P, a national authority can rise the $\mathrm{CCB}$ rate to a ect banks' balance sheet $m$ anagem ent and reduce their exposure to intemational borrow ing. In addition when system risks abate in one econom y, leading to capital flow reversals, national authorities $m$ ay release the bu er thus loosening the banks' funding constraint to address the procyclicality of capitalflows.

3. Estim ation strategy

W e fit the previous two country D SG E to Eurozone data over the sam ple tim e period 1999Q 1-2013Q 4 using B ayesian tedhniques. W e estim ate structural param eters and the sequence of shocks by follow ing the sem inal contributions of Sm ets and W outers (2003, 2007) and Christiano et al (2005). For a detailed description, we refer to the original papers.

\subsection{Data}

W esplit the Eurozone in two groups adopting the core-periphery dichotom $y$ as in $Q$ uint and Rabanal (2014) and Poutineau and Verm andel (2015) . Core countries gather A ustria, B elgium, G erm any, Finland, France, Luxem bourg and N etherlands w hile peripheral countries inchude Spain, G reece, Ireland, Italy and Portugal. The model is estim ated with Bayesian m ethods on Eurozone quarterly data over the sam ple period 1999Q 1 to 201304 , which m akes 60 observations for each observable variable. Conceming the transform ation of series, the point is to $\mathrm{m}$ ap non-stationary data to a stationary m odel. Data which are 
known to have a trend (nam ely G D P, consum ption, investm ent, corporate loan and interbank supply) or unit root are $m$ ade stationary in two steps. First, we divide the sam ple by the population. Second, data are taken in logs and we use a first di erence filtering to obtain grow th rates. In addition, real variables are deflated by the H IC P price index and we rem ove the seasonal com ponent in the data using a m ultiplicative decom position. Furtherm ore, we dem ean the data as we do not use the inform ation contained in the observable $m$ ean. Interest rates are set on a quarterly basis by dividing them by 4 . Since hours w orked are not observable for the Euro A rea, we adopt the sam e m odelling strategy as Sm ets and W outers (2003) to identify TFP shodks using em ploym ent as a proxy for hours worked. Em ploym ent is divided by the working population index, taken in logs and dem eaned. To $m$ ap em ploym ent to hours worked in our $m$ odel, we introduce an auxiliary equation for each country which states that only a share $\theta_{1}^{E},[0,1)$ of firm $s$ is allowed to adjust its level of em ploym ent $\hat{\epsilon}_{, t}$ to its optm al labor dem and $\mathrm{H}_{\mathrm{i}, \mathrm{t}}^{\mathrm{d}}$ :

$$
\hat{\epsilon}_{, t}=\beta \hat{\epsilon}_{t, t+1}+1-\beta \theta_{i}^{E} \quad 1-\theta_{i}^{E} / \theta_{i}^{E} \log H_{i, t}^{d} / \bar{H}^{d}-\hat{\epsilon}_{, t} .
$$

The vector of observable variables reads as:

$$
Y_{t}=100\left[\hat{y}_{i, t}, \hat{\epsilon}_{t, t}, \quad \hat{i}_{t, t}, \hat{r}_{i, t}, \hat{n}_{i, t}^{c}, \quad w_{i, t}, r_{i, t}^{D}, \quad \hat{i}_{i, t}^{s}, \quad \phi_{i, t}^{s}, r_{t}\right] \text { for } i=\{c, p\} .
$$

\subsection{Calibration, priors and model assumptions}

$W$ e fix a sm all num ber of param eters com m only used in the literature of real business cycles m odels whion are weakly identified. The discount factor $\beta$ is set at 0.99 , the depreciation rate $\delta$ at 0.025 , the capital share $\alpha$ at 0.38 , the share of steady state hours worked $\bar{H}$ at 1 , the spending to G D P ratiog at 24\%. ${ }^{21}$ Conceming $P$ and $w$ (the substitutability between final goods and labor), we consider the calibration at 10 as in Sm ets and W outers (2007). R egarding financial param eters, we fix $\bar{N} / \bar{K}$ (the net worth to capital) ratio to 0.40 to be consistent $w$ ith the observed debt-tofinancial assets ratio of non-financial cor-

\footnotetext{
${ }^{21}$ This calibration offers a consumption-to-out put ratio of $55.45 \%$ (vs $57.31 \%$ in the data) and investmentto-output ratio of $20.55 \%$ (vs $20.70 \%$ in the data).
} 
porations which fluctuates between $50 \%$ and $65 \%$ since 1999 . The steady state value of spreads and the bank balance sheet are calibrated on their averages observed over the sam ple period in the Euro A rea: $\bar{R}-\bar{R}^{\bar{D}}=1.66 / 400, \bar{R}^{L}-\bar{R}^{\mathrm{D}}=3.67 / 400, \bar{D} / \bar{L}^{\mathrm{s}}=0.46, \mathrm{rwa}=\bar{V}=0.10$ and $\overline{\mathrm{IB}} / \bar{L}^{\mathrm{s}}=0$ 20. The capital regulation cost $X^{\mathrm{k}}$ is set at 11 as in G erali et al. (2010) to replicate the response of credit and interest rate to a capital requirem ent rise.

For substitution param eters for conporate and interbank bans $U$ and $\xi$ as well as for the fraction of illiquid banks $\lambda$, to our know ledge there are no em pirical analysis using bank level data that provides an estim ation of these param eters. W e rely on the previous fit exercise of P outineau and Verm andel (2015) by calibrating $\lambda$ at 0.38 and $U, \xi$ at 1.1. The latter calibration for substitution param eters is rather conservative by allow ing very low substitution e ects between hom e and foreign loans.22 The quarterly share of defaulting firm $s^{\prime}$ projects $1-\eta^{E}$ is fixed at $0.025 / 4,{ }^{23}$ and the auditing cost $\mu^{B}$ at $0.10,{ }^{24}$ those values are very sim ilar to B emanke et al. (1999). We com pute the param eter goveming the relative size of the core area $n$ at 0.58 as in Kolasa/ (2009), which is the share im plied by nom inal GD P levels averaged over the period 1999-2013. W e calibrate sym m etrically the adjustm ent cost on deposits $X_{i}^{D}$ at 0.0007 as in Schm itt-G rohé and U ribe (2003) to rem ove an unit root com ponent generated by the two-country set-up. F inally, the lower bound $W_{\text {min }}$ and the shape $\mathrm{K}$ of the Pareto distribution are endogenously determ ined by the $m$ odel equations assum ing a risk-free econom $y$ w ith no spread and default, we obtain: $\omega_{\text {min }}=1-\bar{N} / \bar{K}$ and $K=\bar{K} / N$. Our calibration delivers for the $m$ ain endogenous variables the follow ing steady state: $\omega^{\mathrm{C}}=0.6015, \varepsilon^{\mathrm{D}}=-2.41, \varepsilon^{\mathrm{L}}=4.37, \mathrm{r}^{\mathrm{L}}=0.0192$ and $\mathrm{r}^{\mathrm{K}}=0.0166$.

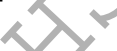

\footnotetext{
${ }^{22}$ In contrast,Brzoza-Brzezina et al. (2015) assign a value of 6 to their substitution parameter, which is rather high with respect to the literature of trade. In general, substitution parameters for goods market are rather low and usually remain between 1 and 2 as in Quint and Rabanal (2014) or Poutineau and Vermandel (2015).

${ }^{23}$ This is consistent with corporate default statistics from Moody's, the rating agency, which show an average default rate on (non-US) non-financial corporate bonds of $0.75 \%$ for the period $1989-2009$, as shown by Darracq-Pariès et al. (2011). The other rating agency Standards \& Poor's evaluates the rate of default for the period $1991-2014$ to $0.58 \%$. We consider a default rate of $0.63 \%$ which is in the ballpark of the numbers found by rating agencies.

${ }^{24}$ The auditing cost cannot be observed as few data on loan losses are publicly available for reasons of confidentiality. Dermine and De Carvalho (2006) find using bank level data that these costs critically depends on the size of the loans: recovery costs on smaller loans are substantially higher than on large loans, $4.1 \%$ vs. $0.9 \%$. In addition, once the contentious department has to rely on external lawyers, the recovery costs rise to $10.4 \%$.
} 
O ur priors are listed in Table B .7. O verall, they are either relatively uninform ative or consistent $w$ th earlier contributions to Bayesian estim ations. For a m ajority of new K eynesian m odels' param eters, i.e. $\sigma_{i}^{L}, h_{i}^{C}, \theta_{i}^{P}, \xi_{i}^{P}, \theta_{i}^{W}, \xi_{i}^{W}, \theta_{i}^{E}, X_{i}^{L}, \psi_{i}, \varphi^{\mathrm{T}}, \varphi^{\Delta y}$ and shodk processes param eters, we use the prior distributions close to Sm ets and W outers (2003, 2007). Calvo probabilities for rates have the sam e uninform ative priors as for prices/wages while loans habits are given a prior m ean $0.5 \mathrm{w}$ ith standard deviation 0.2 . O ur prours for openness param eters are based on their observed average over the sam ple period. Substitutabilities between hom e/foreign credit and final goods are set to 2 with standard deviations of $0.50 . W$ e set the prior for the elasticity of the extemal finance prem ium $\kappa_{i}$ to a beta distribution w ith prior m ean equal to 0.05 and standard deviation 0.02 consistent $w$ ith prior inform ation of $\mathrm{G}$ ilchrist et al. (2009). Finally, in order to catch up the comrelation and co-m ovem ents between countries' aggregates, we est im ate the cross-country correlation between structural shodks, associated priors are inspired by in Jondeau et al. (2006) and K olasa (2009), we set the m ean of the prior distribution for shock correlations betw een core countries and peripheral countries at $0.2 \mathrm{w}$ ith a standard deviation at 0.2 .

$\mathrm{F}$ inally, regarding bank capital regulation for the fit exercise, we disable the $\mathrm{m}$ acropnudential instrum ent by fixing the C CB rate to its determ inistic steady state value:

$$
\mathrm{v}_{\mathrm{i}, \mathrm{t}}=\overline{\mathrm{V}}
$$

This assum ption is reasonable for tw o $\mathrm{m}$ ain reasons. F irst over the sam ple period, capital regulation has been $m$ ainly dom inated by the B asel IA coords characterized by fixed capital requirem ent ratios. Second, even through the adoption of the B asel IIIA ccords allow s E uro A rea countries to em ploy the countercyclical capital bu er as a shield against the build up of financial im balances, it has not been yet em ployed by a participant of the m onetary union. 25

${ }^{25}$ The ESRB offers on its website an interactive map of the Euro Area on countercyclical capital buffers To this date, only Sweden and Norway have activated the CCB rate in the European Union but both of these countries are not Euro Area participants. 


\subsection{Estimation results}

The m ethodology em ployed is standard to the B ayesian estim ations ofD SG E m odels. ${ }^{26}$ Table B .7 reports estim ation results which sum m arizes the m eans and the 5th and 95th percentiles of the posterior distributions w hile the latter are draw $n$ in $F$ igure B .6. A coording to this figure, prior and posterior distributions are relatively di erent show ing that the data were fairly inform ative. Several param eters are well identified for one country but w eakly for the other econom $y$, we decide to keep these param eters in the fit exencise after checking that their weak identification does not a ect our estim ations (ie. calibrating these param eters and re-estim ating the m odel provides very sim ilar results). W hile our estim ates of the standard param eters are in line $\mathrm{w}$ ith the literature (see for instance Sm ets and W outers (2003) and $Q$ uint and R abanal (2014)), severalobsenvations are w orth m aking by com $m$ enting the $m$ ean of the posterior distribution of stnuctural param eters.

First regarding asym m etries in business and credit cycles between the core and the periphery, they are mainly driven by the standard deviation of shocks which are larger in peripheral econom ies. In particular, ine ciency shocks for wages and prices are m ore volatile in periphery which $\mathrm{m}$ ay constitute an issue in the im plem entation of a single m onetary policy. In the sam e vein for m acroprudential regulation, the presence of heterogenous financial shocks in term s of volatility questions the perspective of a single federal $\mathrm{m}$ acroprudential authority.

Second tuming to structuralparam eters, we find an im portant di erence betw een countries regarding param eter $\theta_{1}^{E}$ that determ ines the adjustm ent of em ploym ent to the dem and of hours w orked: core countries observe a shuggish response of em ploym ent to the cycle w hile the $m$ irror $m$ age is seen for periphery. Still regarding the labor $m$ arket, wage rigidity and $\hat{x}$

\footnotetext{
${ }^{26}$ The posterior distribution combines the likelihood function with prior information. To calculate the posterior distribution to evaluate the marginal likelihood of the model, the Metropolis-Hastings algorithm is employed. We compute the posterior moments of the parameters using a sufficiently large number of draws, having made sure that the MCMC algorithm converged. To do this, a sample of 250, 000 draws was generated for four chains through parallelization, neglecting the first 50,000 . The scale factor was set in order to deliver acceptance rates of between 20 and 30 percent for each chain. Convergence was assessed by means of the multivariate convergence statistics taken from Brooks and Gelman (1998). We estimate the model using the dynare package of Adjemian et al. (2011). We provide in the online appendix the bayesian IRF of the model which are all fairly consistent with VAR-type models evidence.
} 
indexation param eters are also higher in core countries suggesting that core countries are farther from the optim al allocation characterized by flexible wages and prices. How ever this interpretation is nuanced by G alf (2013) show ing that wage rigidities can, in som e particular situations, play a stabilizing role for the econom y. O ne of these particular situations exposed by G ali (2013) is a m onetary policy w eakly oriented tow ard inflation which can be observed when m onetary policy has hit its low er bound. In the light of this new reinterpretation that m eets the current situation of the Euro A rea, wages and em ploym ent rigidities of core countries $m$ ay have been stabilizing frictions since the financial crisis episode in 2009.

Third, the results related to $m$ arket integration are in line w ith the standard em pirical evidence. In particular, peripheral econom ies are m ore open and dependent to the core area than the opposite, except for interbank facilities. This latter result is hard to reconcile $\mathrm{w}$ ith the em pirical evidence as, before the financial crisis, peripheral econom ies where net recipient of interbank loans that fueled the property boom. This could be a lim itation of the analysis conducted here, how ever by sum m ing both the net entry of comporate and interbank loans, our m odel predicts that peripheral econom ies w ere net recipient of loans consistently $\mathrm{w}$ ith the historical experience of the Euro A rea.

4. The perform ance of M acroprudential P olicy

\subsection{The suboptimality of the federal solution}

The countercyclicalcapital bu er (C C B , henceforth), as defined in the B asel III accords (2010) and ESR B handbook (2014), is an instrum ent designed to contain the procyclicality of the financial sector. It is aim ed at building up a capitalbu er when threats to resitience are high or during periods of excessive credit grow th and can be released when system ic risks abate. The ESR B has selected the credit-to-gdp gap as a leading indicator to signal upcom ing crises that the CCB is m eant to $\mathrm{m}$ itigate. A natural translation of the CCB 's objective in our setup corresponds to the $m$ inim ization of the variance of the credit-to-gdp 
ratio in the m onetary union $?^{27}$

$$
L=\sigma_{L / Y}^{2}+\lambda_{Y} \sigma_{Y}^{2}+\lambda_{V} \sigma_{V}^{2},
$$

where $\sigma_{L / Y}^{2}, \sigma_{Y}^{2}$ and $\sigma_{v}^{2}$ denote respectively the unconditional variance of the credit-to-gdp ratio, output and policy tool $v_{i, t}$ while param eters $\lambda_{Y}$ and $\lambda_{v}$ are weights on output and CCB . This ad-hoc boss function L bonowed from Angelini et al. (2014) is obtained as a weighted average of national loss functions for each area. It is defined as, $\mathrm{L}=\mathrm{nL}_{\mathrm{c}}+$ $(1-n) L_{p}$, where for each country the nationalloss is given by, $L_{i}=\sigma_{i, L / Y}^{2}+\lambda_{Y} \sigma_{i, Y}^{2}+\lambda_{v} \sigma_{i, v}^{2}$. Noticeably, as our m odel features an interbank $m$ arket, the credit-to-gdp ratio is given by the aggregate credit supply divided by output: $\operatorname{ctg}_{i, t}=\left(L_{i, t}^{s}+(1-\lambda) / B_{i, t}^{s}\right) / Y_{i, t}$. As Angeliniet al. (2014), we assum e that $\lambda_{V}=0.10$ and $\lambda_{Y}=0$, how ever in a robustness section we investigate whether our results are sensitive to this calibration.

U sing the criterion (17), we are able to perform a sim ilar exercise as Angelini et al. (2014) by ranking m acroprudential policies selecting C CB rule's coe cients $\varphi_{c}^{u}, \rho_{p}^{u}, \varphi_{c}, \varphi_{p}$. that deliver the sm allest loss. W e search over a four-dim ensional grid over param eters ranges $[0,1)$ for $\rho_{i}^{u}$ and $[0,5]$ for $\varphi_{i}$. A s a benchm ark for com paring our scenarios for CCB im plem entation, we consider the opt im al m onetary policy situation characterized by the optim ized Taylor nule that maxim izes the welfare of households living in the monetary union. Put di erently, the interaction between m onetary and $m$ acropnudential policy follow s a Stackelberg gam e w here m onetary policy is leader by rem oving nom inal ine ciencies in the Euro area through the refinancing rate, follow ed afterw ard by $m$ acroprudentialpolicy which dam pens financial cycles. O ptim al m onetary policy is based on a second order approxim ation to equilibrium conditions of the m odel as in Schm itt-G rohé and U ribe (2007)

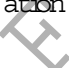

${ }^{27}$ We are aware that the minimization of a loss function rather than a micro-founded welfare criterion is a limitation of our analysis. However, it is also well-known that the usual welfare criterion weakly portrays the trade-off faced by macroprudential authorities between macroeconomic and financial stabilization. A macroprudential policy maximizing the welfare index reduces inflation to the detriment of the financial system which experiences higher volatilities for credit supply and spreads. In response, Woodford (2012) employs an ad hoc loss function that fairly portrays the objective of macroprudential policy. Most of the literature follows Woodford's approach, such as Darracq-Pariès et al. (2011) and Angelini et al. (2014). 
using estim ated param eters of Table B $.7 .^{28}$ O ptim al w eights in the Taylor nule are respectively $\rho=0.99, \varphi^{\pi}=4.38, \varphi^{\Delta y}=0.5$.

F inally, the m inim ization of the variance of the credit-to-G D P gap can be re-interpreted through an allocation problem for authorities. Entrepreneurs' distorted beliefs generate overborrow ing decisions which ine ciently am plify the cycle. By so, entrepreneurs do not intemalize their contribution to the financial am plification. A uthorities thus im plem ent a capital requirem ent policy which can be seen as a Pigouvian tax on banks aim ing at intemalizing the increase of the social cost through higher lending rates to entrepreneurs. ${ }^{29}$ Thus the financialam plification ism easured here through the variance of the credit-to-G D P ratio.

W e evaluate the stabilization perform ance of each m acropndential policy schem e by $\mathrm{m}$ inim izing the second order loss function defined in Equation, 17 subject to linear equilibrium conditions of the estim ated m odel.

Table 2

Loss-based ranking of different macroprudential policy implementation schemes

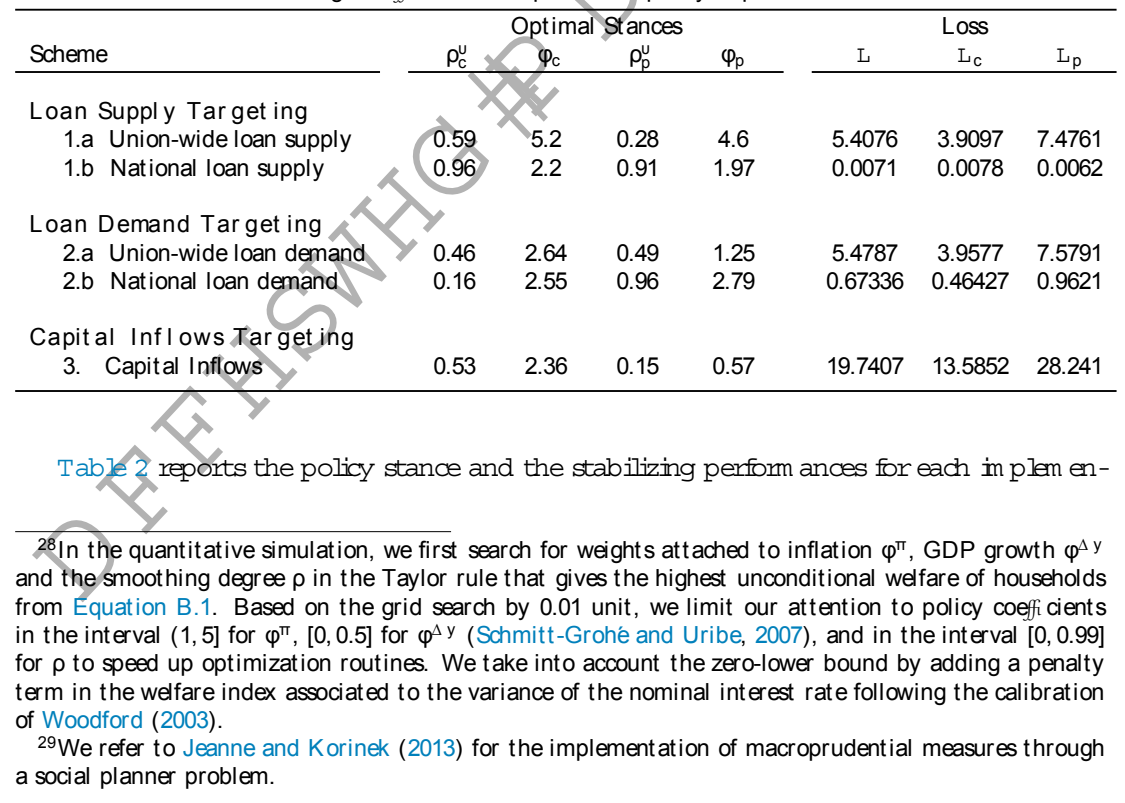



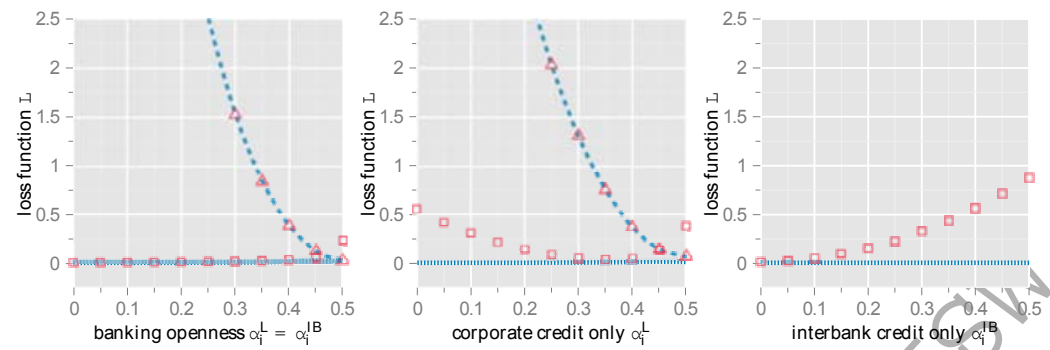

... 1a - union-wide loan supply

$\triangle$ 2a- union-wide loan demand

Imumu 1b - national loan supply

$2 \mathrm{~b}$ - national loan demand

Not e: for each value of the share of foreign loans in the portfolio of entrepreneurs (denoted $\alpha_{i}^{L}$ ) and banks (denoted $\alpha_{i}^{l}{ }^{B}$ ), we compute the optimal macroprudential policy for four different schemes. The loss function is an average between core and periphery detailed in Equation 17. Capital inflows-adjusted policy is not reported as its loss is too high compared to alternative schemes.

Figure 3: The role of cross-border banking in the scheme ranking

tation schem e. The optim al stabilization of the financial system critically depends on the target selected by m acropnudential authorities. U nsurprisingly, we observe a clear ranking favoring operational instrum ents reacting to national ban developm ents (schem es 1 bo and 2 b) that outperform s solutions based on federal loan developm ents (schem es 1 a and 2 a)

A natural question is thus to determ ine the degree of $m$ utual financial cross-border lending flow s that should be observed to a ect this m ain conchusion. Indeed, as underlined by C ecchettiand Tudker (2016) and B edk et al. (2016) a higher banking integration should require a com m on prudential standard (here, the targeting nule) applied appropriately to all parts of the financial system. As a consequence, the e ciency of federal targeting nules (i.e. schem es 1.a and 2.a) is expected to increase w ith the share of cross-border loans while national adjusted should be less e cient. To investigate this question, Figure 3 reportsm inim ized loss functions for di erent levels of cross-border loans. Three com ponent are presented related to an increase in total (nam ely the sum of comporate and interbank) cross-border loans in the left panel, in conporate loans only in the center panel and in interbank bans only in the right panel.

$W$ e can draw three $m$ ain conclusions from $F$ igure 3. First, the interest of conducting 
federal based definition of the credit-to-gdp ratio unsurprisingly increases $w$ ith the size of cross-border flows. A s reported in the first panel, the relative interest of im plem enting a nationaladjusted rule (such as 1.b and 2.b) ism agnified w ith respect to the federal adjusted nule for low er values of $\alpha_{i}^{L}$ and $\alpha_{i}^{B}$. How ever for values of these param eters higher than $25 \%$, the gap in the loss function values tends to decrease significantly. Nevertheless, $m$ acroprudential rules based on a federal definition of the credit to G D P ratio becom es only interesting for a m utual cross-border lending openness lying around 45\%. This figure is rather high w ith respect to the current value of cross-border lending, which $m$ akes this solution not optim al for the $m$ om ent.

Second, this policy outcom e regarding the reduction in the loss function under a federal definition of the credit-to-gdp ratio is m ainly driven by the mutual openness of the corporate credit $m$ arkets. A s reported in the center and right panels, interbank cross-border lending credit has no noticeable im pact on the relative ranking of policy solutions, while the integration of the conporate loan segm ent determ ines the slope of the decrease in the loss function under the federal solution.

Third, even if banking integration clearly enhances the stabilization perform ances of federal-adjusted schem es, a m acropnudential solution targeting the national credit supply rem ains rem arkably e cient $w$ ith a global banking system. For the all spectrum of values of $\alpha_{i}^{L}$ and $\alpha_{i}^{B}$ displayed in panels of $F$ igure 3, CCB reaction to a national definition of the credit-to-gdp ratio determ ines the low est value for the loss function. Thus, our experm ents suggest that even if cross-border linkages are high enough to justify the im plem entation of a federal adjusted solytion, the reaction to national lending conditions rem ains optim al. 1.

\subsection{Contrasting national solutions}

A s underlined in Table 2 our num erical results suggest that the best outcom e for the loss function value is obtained when $m$ acroprudential policy targets the national supply of loans instead of the national dem and for loans (i.e. , accounts for the national and foreign nature of loans contracted in the econom y). The interest of targeting loan supply is easily understandable, as the transm ission channelofm acropnudentialpolicy directly im pacts the $\mathrm{m}$ arginal cost of loan production and, by so, financial interm ediaries. If $m$ acropnudential 
policy targets loan dem and, this direct channel is dam pened, which leads to a low er reduction of the loss function. N ational m acroprudential policies reacting to federal averages do not target the origin of financial im balances as regional divergences in credit cycles are too im portant to have a single federal target. The solution focusing on cross-border lending developm ents (3), is clearly dom inated by all the other im plem entation schem es: in this case, the loss function reaches its highest value, revealing that targeting extemal imbalances is not appropriate as it does not take into account the financial roots of the problem .

To understand these results we sim ulate the dynam ic responses to a negative productivity shodk in core countries and a negative net wealth shodk in peripheral econom ies. ${ }^{30}$ W e concentrate on these two shocks as they are leading drivers of the loan-to-gdp ratio that authorities aim at stabilizing through capital bu er m easures.

F irst, F igure 4 reports the IR F S after a negative productivity shock for each CCB rule $w$ ith respect to the optim alm onetary policy situation. I nder the benchm ark of an optm al m onetary policy (dashed lines), a negative home productivity shock depresses investm ent and activity and im plies ine cient fluctuations in the credit-to-gdp ratio. This shock translates to the peripheral region through trade channels, cross-border lending, m onetary policy reaction and shock comelation. The introduction of nationalm acroprudentialm easures has a clear stabilizing e ect for business cycles of the m onetary union. The release of the bu er eases the bank capital constraint which in tum low ers credit spreads and investm ent fluctuations. However, the targeting regim e determ ining the $\mathrm{CCB}$ rate critically a ects the outcom e the econom $y$ that does not experience the shock and explains the e ectiveness of national credit targeting regim es over federal ones. In a federal targeting regim e ( 1 a and 2 a), both countries react to a com $m$ on average credit-to-gdp ratio which leads the foreign country to react procyclically to foreign shocks. In addition, we do not find clear di erences betw een targeting national credit dem and or supply. F inally C CB rates adjusted to capital inflow $s$ fail at providing $m$ acroeconom ic stability in particular for the peripheral country. The shodk in the core country generates a re-allocation of credit from core to pe-

\footnotetext{
${ }^{30}$ As underlined by Angelini et al. (2014), supply shocks may dominate in normal times, while financial shocks are important in exceptional times.
} 

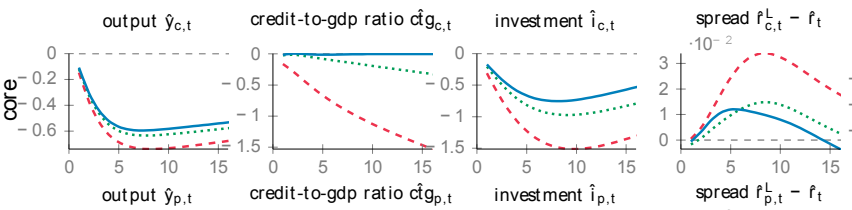

capital buffers $\hat{\mathrm{v}}_{\mathrm{c}}$,

output $\hat{y}_{\mathrm{p}, \mathrm{t}}$

spread $\hat{p}_{\mathrm{p}, \mathrm{t}}^{\mathrm{t}}-\hat{\mathrm{f}}_{\mathrm{t}}$

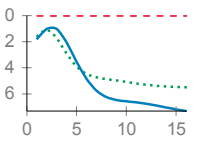

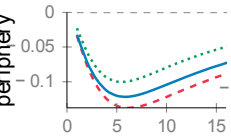
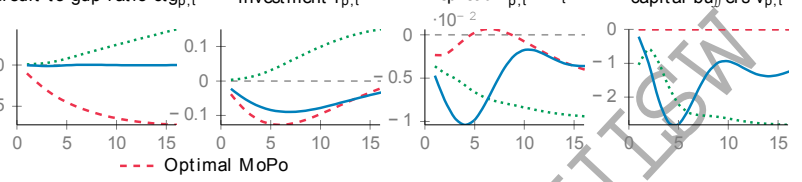

..... Optimal MoPo + MAP (supply union)

Optimal MoPo + MAP (supply national)

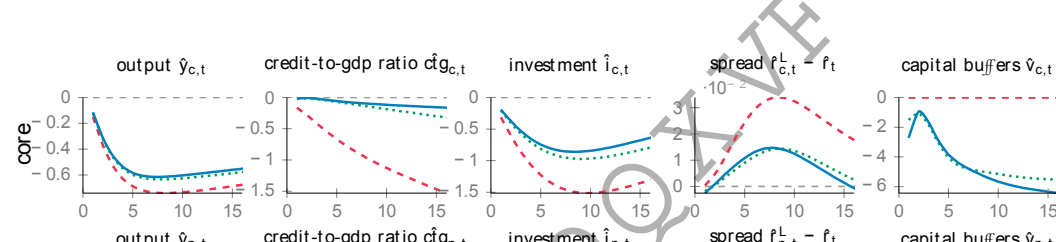

output $\hat{y}_{p, t} \quad$ credit-to-gdp ratio ct $\hat{g}_{p, t}$ investment $\hat{\hat{p}}_{p, t} \quad$ spread $\hat{f}_{p, t}-\hat{f}_{t} \quad$ capital buffers $\hat{\mathrm{V}}_{p, t}$

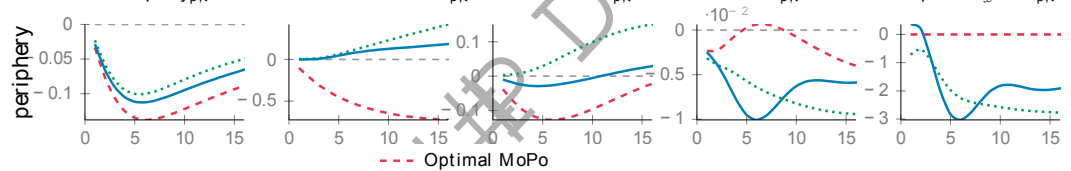

..... Optimal MoPo + MaPru (demand union)

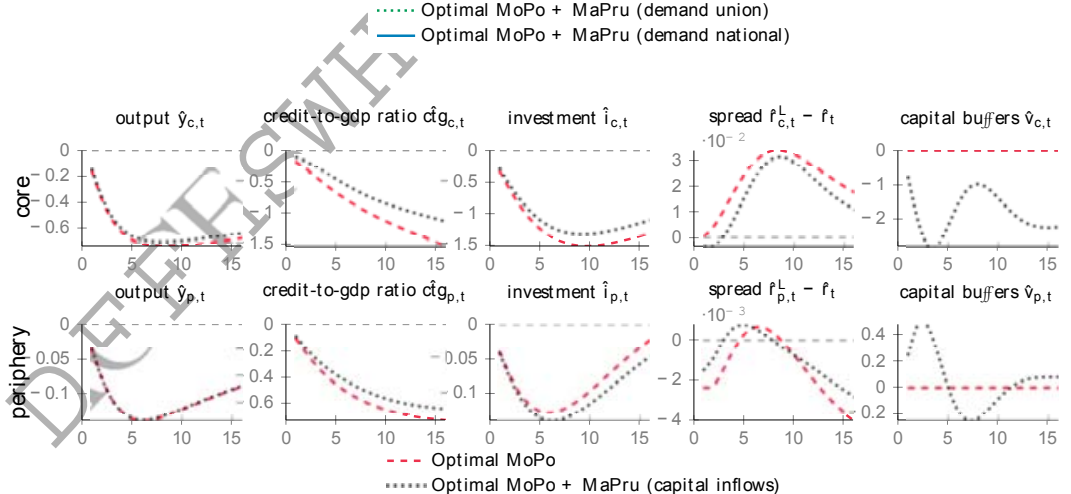

Figure 4: System response to an estimated negative productivity shock in core countries $\eta_{\mathrm{c}, \mathrm{t}}^{\mathrm{A}}$ measured in percentage deviations from steady state under different macroprudential policy rules (domestic or unionwide supply/ demand/ inflows targeting). 
ripheraleconom ies and authorities in peripheraleconom ies procyclically tighten the capital constraint which ine ciently am plifies the crisis.

Second, Figure 5 depicts the $\mathbb{R}$ Fs after a negative stodk $\mathrm{m}$ arket shock in peripheral econom ies. Under the optim alm onetary policy benchm ark (dashed lines), this shodk deteriorates the bonrow ing conditions of entrepreneurs, thus incurring a large decline in output and investm ent through the extemal finance prem ium channel. Consequently, the creditto-gdp gap experiences a large decline ine ciently driven by the biased expectations of entrepreneurs. O ur $\mathrm{m}$ ain results regarding the im plem entation of $\mathrm{m}$ acroprudential $\mathrm{m}$ easures are sim ilar to the productivity shodk. National credit targeting is preferred to a federal one as the latter exacerbates fluctuations for the country that does not experience the shodk, creating a spillover e ect. The sam e procyclicalm echanism is observed for the capital inflow s targeting schem e. F inally, targeting the dem and or supply of credit provides very $\operatorname{sim}$ ilar responses.

Table 3

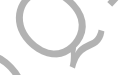

Macroeconomic performances of different implementation schemes in comparison to the optimal policy benchmark

\begin{tabular}{|c|c|c|c|c|c|c|c|c|c|}
\hline \multirow[b]{3}{*}{ Scheme } & \multicolumn{8}{|c|}{ Standard deviations (\%) } & \multirow{3}{*}{$\begin{array}{l}\text { Correlation } \\
\operatorname{corr}\left(\hat{y}_{c, t}, \hat{y}_{p, t}\right)\end{array}$} \\
\hline & \multirow[b]{2}{*}{$\hat{y}_{c, t}$} & \multirow{2}{*}{\multicolumn{2}{|c|}{$\begin{array}{l}\text { Jore } \\
\text { i } \hat{b}_{c, t}\end{array}$}} & \multirow[b]{2}{*}{$\hat{\mathrm{s}}_{\mathrm{c}, \mathrm{t}}^{\mathrm{L}}$} & \multicolumn{4}{|c|}{ Periphery } & \\
\hline & & & & & $\hat{y}_{p, t}$ & $\hat{I}_{\mathrm{p}, \mathrm{t}}^{\mathrm{s}}$ & $i \hat{b}_{p, t}$ & $\hat{\mathrm{s}}_{\mathrm{c}, \mathrm{t}}^{\mathrm{L}}$ & \\
\hline \multicolumn{10}{|l|}{ Monet ary Policy Only } \\
\hline Benchmark & & & 100 & 100 & 100 & 100 & 100 & 100 & 0.15 \\
\hline \multicolumn{10}{|l|}{ Loan Supply Tar get ing } \\
\hline 1.a Union-wide loan sup & 91.57 & 91.95 & 75.11 & 127.47 & 103.88 & 113.45 & 73.86 & 105.96 & 0.15 \\
\hline 1.b National Ioan supply & 79.67 & 76.60 & 74.48 & 130.46 & 95.06 & 86.19 & 73.93 & 120.19 & 0.46 \\
\hline \multicolumn{10}{|l|}{ Loan Demand Tar get ing } \\
\hline 2.a Union-wide loan demand & 91.58 & 92.06 & 75.1 & 127.29 & 103.79 & 112.92 & 73.96 & 105.58 & 0.16 \\
\hline 2.b National loan demand & 82.89 & 92.94 & 71.73 & 137.08 & 76.24 & 63.42 & 76.19 & 116.41 & 0.44 \\
\hline \multicolumn{10}{|l|}{ Capital InfI ows Target ing } \\
\hline 3 Capital Inflows & 93.42 & 138.3 & 73.27 & 156.67 & 96.33 & 79.92 & 88.94 & 90.46 & 0.37 \\
\hline
\end{tabular}

A coounting for all shocks of the m odel, Table 3 reports the standard deviation of activity, conporate and interbank loans and interest rate spread under altemative policy schem es. W e contrast our results $w$ ith respect to the optim al m onetary policy (w ithout prudential regulation) to m easure how the conduct of $m$ acroprudential $m$ easures have de- 

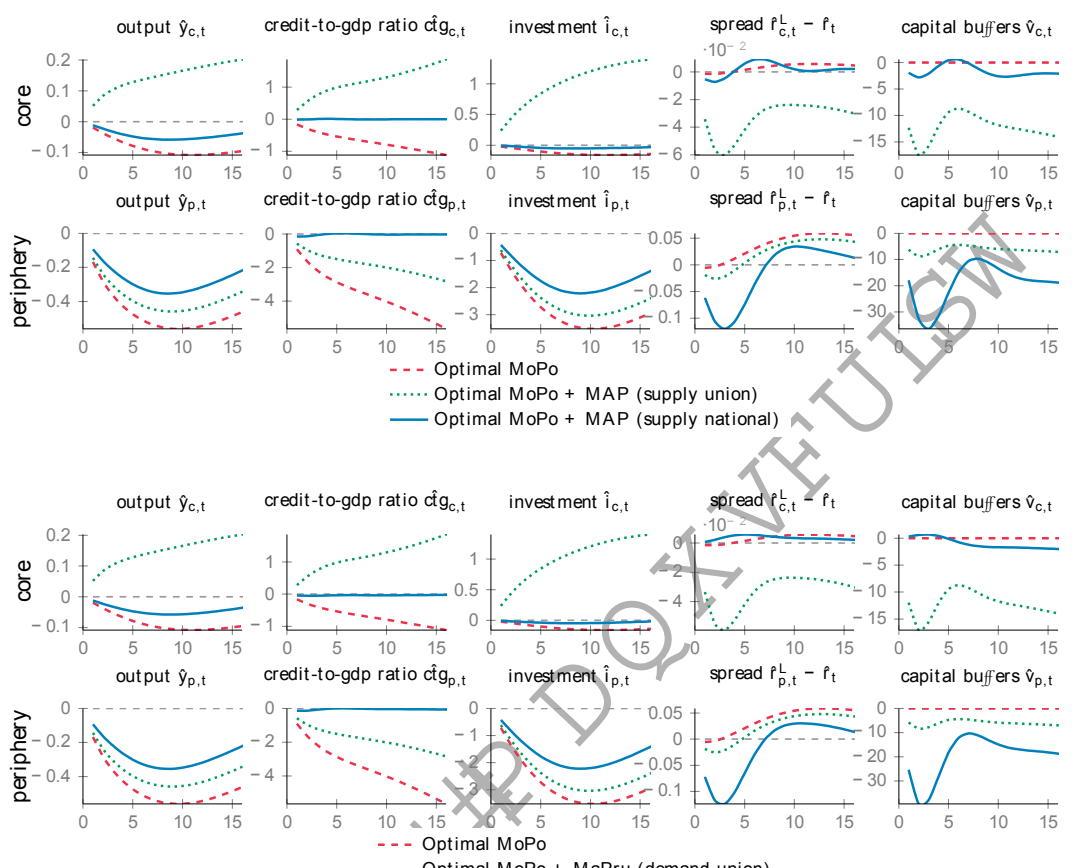

Optimal MoPo + MaPru (demand union)

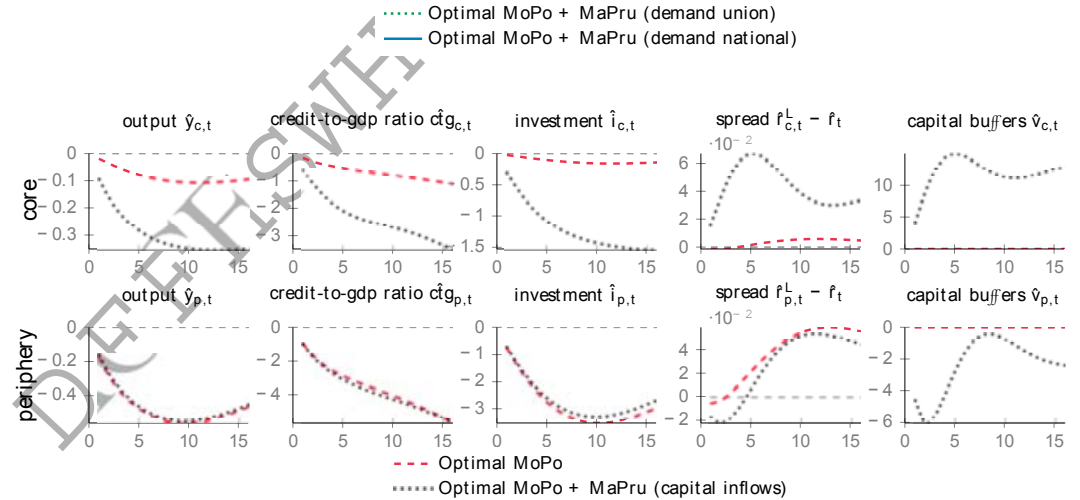

Figure 5: System response to an estimated negative firms net wealth shock in peripheral countries $\eta_{p, t}^{N}$ measured in percentage deviations from steady state under different CCB regulation schemes (domestic or union-wide supply/ demand/ inflows targeting). 
creased/increased the standard deviation of endogenous variables for each country. This exercise $m$ easures how the stabilizing gains are distributed between countries. W e also report business cycle synchronization statistics, as m easured by the comrelation of output between econom ies, to evaluate whether the schem e is able to sm ooth the heterogeneity betw een Euro A rea participants.

O verall, the highest gains can be obtained by adopting m acropnudential policy $m$ easures reacting to national developm ents in the credit-to-gdp ratio. The reaction of the $m$ acroprudential instrum ent to other $m$ easures of the credit-to-gdp ratio loaged on either loan dem and or federal averages) leads to less reduction in the standard deviation of these aggregates. How ever, the im plem entation of $\mathrm{m}$ acroprudential policy is not a free lunch since the building up of a capitalbu er m echanically increases the volatility of the spread when stabilizing the debt-to-G D P ratio. ${ }^{31}$

In addition, we observe a natural link between loan-to-G D P stabilization and business cycle synchronization, show ing that the im plem entation of national-adjusted m acropnudential policies sm ooths the heterogeneity across regions. Such a result is interesting for m onetary policy m akers, as the e ectiveness of a single m onetary policy critically depends on business cycle synchronization betw een m onetary union participants. Thus the enhanced cycle synchronization partially solves the Euro A rea's problem of a "one-size-fits-all" m onetary policy.

Contrasting the nationaldem and and national supply targeting solutions, we find that their e ectiveness are clearly di erent according to the country considered. As an exam ple, the supply side oriented policy fits the situation of core econom ies, while the one oriented tow ards the dem and of credit m eets the situation of peripheral econom ies in term s of $m$ acroeconom ic stabilization. Core countries should thus focus on the stabilization of its banks while peripheral econom ies should stabilize its borrowers. H aving asym m etric targets betw een regions of the Eurozone could be an interesting perspective to im plem ent stabilization policies.

\footnotetext{
${ }^{31}$ The variability of the lending spread is a leading indicator of financial distress, Woodford (2012) sets its stabilization as an objective for monetary policy making with financial frictions.
} 
Finally the capital inflow s targeting solution fits well peripheral econom ies that were net recipient of foreign claim s before the 2009 crisis. How ever, this policy is harm ful for core countries, a ected by an increase in the volatility of loans and of the credit spread. o ver the sam ple tim e period, core countries were net exporter of loans by fueling property boom s in peripheral econom ies through interbank lending, this capital outflow involves an ine cient and durable reduction of the $\mathrm{CCB}$ rate enhancing the volatility of credit dom estically. W hile capital controls appears to be a prom ising tool for Periphery, it is clearly unsuited to countries experiencing capital outflow s.

\section{A dditional sensitivity analysis}

This section assesses the robustness of our results $\mathrm{w}$ ith respect to som e key param eters of the m odel and to the nature of shodks encountered in the econom $y$.

\subsection{Loss function calibration}

Table 4

Sensitivity analysis of scheme ranking to different calibrated parameters

\begin{tabular}{|c|c|c|c|c|c|c|}
\hline & & \multicolumn{5}{|c|}{ Euro area loss $\mathrm{L}$} \\
\hline & & & 1.b & $2 . a$ & $2 . b$ & 3 \\
\hline \multirow[t]{3}{*}{ Loss output stabilization } & $\lambda_{y}=0$ & 5.4076 & 0.0071 & 5.4787 & 0.67336 & 19.7407 \\
\hline & & 6.0138 & 0.4063 & 5.9196 & 1.0906 & 16.7659 \\
\hline & लy 20 & 6.5325 & 0.8036 & 6.5119 & 1.5042 & 20.8989 \\
\hline \multirow[t]{3}{*}{ Loss policy instrument } & $\lambda_{v}=0$ & 5.4063 & 0.0004 & 5.5147 & 0.66152 & 19.9706 \\
\hline & & 5.7099 & 0.28443 & 5.7186 & 0.97562 & 20.1045 \\
\hline & & 5.9328 & 0.53581 & 5.9252 & 1.1936 & 20.4273 \\
\hline \multirow[t]{3}{*}{ Loan substitutability } & $\nabla, \xi=0$ & 5.5082 & 0.0072 & 5.4190 & 0.67025 & 19.7962 \\
\hline & & 5.5206 & 0.0068 & 5.5392 & 0.6914 & 20.2309 \\
\hline & & 5.5372 & 0.0067 & 5.5298 & 0.7056 & 20.9558 \\
\hline \multirow{3}{*}{ Share of core countries } & $\mathrm{n}=0.4$ & 5.5641 & 0.0069 & 5.5485 & 0.0868 & 19.0729 \\
\hline & $\mathrm{n}=0.5$ & 5.6804 & 0.0069 & 5.7378 & 0.3138 & 19.7849 \\
\hline & $\mathrm{n}=0.6$ & 5.4134 & 0.0071 & 5.4053 & 0.78181 & 20.2335 \\
\hline \multirow[t]{3}{*}{ Flexible interest rates } & $\theta_{1}^{L}=0$ & 5.9139 & 0.0058 & 5.8096 & 0.65304 & 17.8474 \\
\hline & $\theta_{i}^{D}=0$ & 5.8987 & 0.0074 & 5.8685 & 0.66579 & 16.6966 \\
\hline & $\theta_{i}^{L}=\theta_{i}^{D}=0$ & 5.9067 & 0.0059 & 5.8446 & 0.66382 & 21.3504 \\
\hline
\end{tabular}

Not e: $\lambda_{y}$ and $\lambda_{v}$ denote respectively weights on output and policy tool volatities in the macroprudential loss function, $v$ is the substitution degree between home and foreign credit varieties and $n$ denotes the share of core countries in terms of real GDP in the euro area. Losses are evaluated using the average of core and peripheral countries volatilities.

F irst, Table 4 reports the sensitivity analysis of the $m$ ain results to the calibrated value of som e underlying param eters. The first experim ents focus on the w eight param eters of the 
loss function of $m$ acroprudential authorities. As reported, the ranking of policies rem ain una ected by the value of these param eters. An increase in the policym akers preferences for output (denoted $\lambda_{y}$ ) or the penalization of the variance of capital requirem ents (denoted $\lambda_{v}$ ) increases the loss. Tuming to structural param eters (nam ely the degree of substitutability betw een di erent varieties of loans $\mathrm{v}$ and $\mathrm{n}$ the share of core countries in the monetary union) the sensitivity analysis does not alter the ranking of $m$ acropnudential decisions. As observed, an increase in the size of the core countries' group has opposite results on the value of the loss, depending on the dim ension of the credit-to-gdp ratjo that is taken into account in the reaction of $\mathrm{m}$ acropnudential policy. The loss decreases for schem es based on a reaction to national loan developm ents while it increases when the m acroprudential instrum ent reacts to the federal value of the ratio. H ow ever, the gap betw een the loss values rem ain so high that the ranking between national and federal solutions is left una ected. R egarding the nom inalrigidities on interest rates, thus reflecting the im perfect pass-through of both $m$ onetary and $m$ acroprudential policies, disabling this nom inal friction does not a ect the ranking too.

\subsection{Nature of shocks}

Second, Table 5 reports the sensitivity analysis of the $\mathrm{m}$ ain results to the nature of shocks encountered in the economy. W e distinguish between supply (productivity shodks), dem and (gathering public spending shodks, preference shodks and investm ent shocks) and financial shodks (gathering shodks on the collateral of conporate lending, on riskiness of investm ent projects and cost push shodks on deposit). A s underlined by Angelini et al. (2014) , supply and dem and shocksm ay dom inate in norm alt'm es, whilefinancialshodks are im portant in exceptional tim es. For each shodk, we contrast the consequences of adopting one of the macroprudential schem e adopted for the definition of the credit-to-gdp ratio (1a to 3). A s observed, the relative ranking of the policy schem e is not altered by the nature of shocks encountered in the econom $y$, as the solution based upon the reaction of authorities to the fluctuations in the national loan supply to G D P dom inates all the other possibilities. H ow ever, the value of the loss fluctuates and it is higher for financial shocks. Furtherm ore, a closer look at the $m$ acroprudential param eters show s that the nature of the shodk a ects 
Table 5

Robustness check: optimal monetary and macroprudential Policies conditional on shocks

\begin{tabular}{|c|c|c|c|c|c|c|c|c|c|c|c|}
\hline \multirow[b]{3}{*}{ Scheme } & & \multirow{2}{*}{\multicolumn{3}{|c|}{$\begin{array}{l}\text { Monetary } \\
\text { Policy }\end{array}$}} & \multirow{2}{*}{\multicolumn{4}{|c|}{$\begin{array}{c}\text { Macroprudential } \\
\text { Policy }\end{array}$}} & \multicolumn{3}{|c|}{ Loss } \\
\hline & & & & & & & & & Union & Core & Periph \\
\hline & & $\rho$ & $\varphi^{\pi}$ & $\varphi^{\Delta y}$ & $\rho_{\mathrm{c}}^{\mathrm{U}}$ & $\varphi_{\mathrm{c}}$ & $\rho_{\mathrm{p}}^{u}$ & $\varphi_{p}$ & $\mathrm{~L}_{\mathrm{u}}$ & $\mathrm{L}_{\mathrm{c}}$ & $L_{p}$ \\
\hline \multicolumn{12}{|c|}{ Suppl y Shocks } \\
\hline 1.a & Union-wide loan supply & 0.94 & 5 & 0.5 & 0.82 & 0.30 & 0.41 & 3.86 & 1.3139 & 0.95417 & 1.8107 \\
\hline 1.b & National Ioan supply & 0.94 & 5 & 0.5 & 0.95 & 2.72 & 0.86 & 2.58 & 0.0027 & 0.0041 & 0.0007 \\
\hline 2.a & Union-wide loan demand & 0.94 & 5 & 0.5 & 0.90 & 3.54 & 0.39 & 0.50 & 1.3189 & 0.95679 & 1.819 \\
\hline 2.b & National loan demand & 0.94 & 5 & 0.5 & 0.46 & 2.49 & 0.48 & 2.46 & 0.065797 & 0.04746 & 0.091119 \\
\hline 3 & Capital Inflows & 0.94 & 5 & 0.5 & 0.81 & 3.63 & 0.43 & 0.98 & & 1.5535 & 2.5065 \\
\hline \multicolumn{12}{|c|}{ Demand Shocks } \\
\hline $1 . a$ & Union-wide Ioan supply & 0.99 & 1 & 0.5 & 0.66 & 3.07 & 0.62 & 2.16 & 0.20432 & 0.14956 & 0.27993 \\
\hline 1.b & National Ioan supply & 0.99 & 1 & 0.5 & 0.94 & 2.52 & 0.64 & 2.52 & 0.0035 & 0.0039 & 0.0029 \\
\hline 2.a & Union-wide loan demand & 0.99 & 1 & 0.5 & 0.58 & 2.61 & 0.39 & 2.37 & 0.2051 & 0.1504 & 0.2806 \\
\hline 2.b & National loan demand & 0.99 & 1 & 0.5 & 0.05 & 2.35 & 0.80 & 2.69 & 0.7980 & 0.5139 & 1.1903 \\
\hline 3 & Capital Inflows & 0.99 & 1 & 0.5 & 0.76 & 3.68 & 0.08 & 0.41 & 12.7015 & 11.5068 & 14.3513 \\
\hline \multicolumn{12}{|c|}{ Financial Shocks } \\
\hline 1.a & Union-wide loan supply & 0 & 1.48 & 0.5 & 0.15 & 1.60 & 0.24 & 3.35 & 0.5895 & 0.4308 & 0.8086 \\
\hline 1.b & National Ioan supply & 0 & 1.48 & 0.5 & 0.92 & 2.21 & 0.94 & 1.66 & 0.0023 & 0.0014 & 0.0035 \\
\hline 2.a & Union-wide loan demand & 0 & 1.48 & 0.5 & 0.06 & 1.94 & 0.26 & 3.58 & 0.5900 & 0.4301 & 0.8107 \\
\hline 2.b & National loan demand & 0 & 1.48 & 0.5 & 0.98 & 1.72 & 0.85 & 1.37 & 0.0054 & 0.0038 & 0.0077 \\
\hline 3 & Capital Inflows & 0 & 1.48 & 0.5 & 0.30 & 0.47 & 0.96 & 4.63 & 2.6168 & 2.1119 & 3.3141 \\
\hline
\end{tabular}

Not e: each group of shocks is composed of core and peripheral shocks and their associated cross-correlation. Supply shocks group gathers productivity shocks $\eta_{i, t}^{A}$; Demand shocks group gathers spending $\eta_{i, t}^{G}$, preferences $\eta_{i, t}^{U}$ and investment $\eta_{i, t}^{1}$; Financial shocks gathers collateral crunch $\eta_{i, t}^{N}$, riskiness $\eta_{i}^{Q}$, and deposit cost-push $\eta_{i, t}^{D}$ innovations.

the contem poraneous policy stance of regional authorities. A s observed, for real shocks, the contem poraneous reaction of core countries authorities tends to be higher for supply shodks w hile peripheral countries are $m$ ore reactive for dem and shodks. This latter feature is also observed for exceptional tim es.

\subsection{Structural financial asymmetries}

Table 6

Sensitivity analysis of scheme ranking to financial structural asymmetries

\begin{tabular}{llccccc}
\hline & & \multicolumn{5}{c}{ Euro area loss $\mathrm{L}$} \\
\cline { 3 - 7 } & & $1 . \mathrm{a}$ & $1 . \mathrm{b}$ & $2 . \mathrm{a}$ & $2 . \mathrm{b}$ & 3 \\
\hline Benchmark & & 5.4076 & 0.0071 & 5.4787 & 0.67336 & 19.7407 \\
Firms rate of default & $1-\overline{\mathrm{\eta}}_{\mathrm{p}}^{\mathrm{E}}=0.0125$ & 6.6312 & 0.0078 & 6.6535 & 0.58638 & 22.6661 \\
Share of illiquid banks & $\lambda_{\mathrm{p}}=0.48$ & 6.0702 & 0.0078 & 6.3512 & 1.9242 & 21.7665 \\
Corporate net wealth-to-assets ratio & $\mathrm{N}_{\mathrm{p}} / \overline{\mathrm{K}}_{\mathrm{p}}=0.2$ & 7.4030 & 0.0070 & 7.3528 & 0.55023 & 22.8376 \\
\cline { 3 - 7 } Bank leverage ratio & $\overline{\mathrm{BK}}_{\mathrm{c}} / \mathrm{A}_{\mathrm{c}}=0.06$ & 6.5421 & 0.0163 & 6.5513 & 0.64037 & 19.651 \\
\hline
\end{tabular}


Third, we investigate whether structural asym m etries a ect the ranking of the m odel, results are reported in Table 6 . In the benchm ark setup developed in the paper, we assum ed that $m$ ost of the endogenous variables in the determ inistic steady state were sym m etric between countries. How ever this assum ption is questionable, in particular regarding the asym $m$ etries in the financialsector which $m$ ay be an im portant feature form acropnudential policym aking. As a first exercise, we exam ine whether the sym m etry assum ption on the default rate of entrepreneurs $m$ atters for the schem e ranking. Since we cannot observe the default rate of entrepreneurs, we use as a proxy the share of non-perform ing loans in the balance sheet of banks in BankScope database. W e find that the share of nonperform ing loans is on average tw ice higher in Periphery and calibrate the defaulting share of entrepreneurs accordingly. W e find that this structural asym m etry does not a ect the ranking, how everw e observe a sm all reduction of the gap between the dem and-adjusted and the supply-adjusted $\mathrm{m}$ acropnudential policy. W e also investigate the im plications of crosscountry heterogeneity in the share of illiquid banks operating in the interbank $m$ arket. W e proxy this param eter through the num ber of banks borrow ing on the unsecured m oney $m$ arket provided by G arcia-de A ndoain et al. (2014). W e find that on average the share of banks borrow ing on the interbank $m$ arket is $25 \%$ higher in Periphery, we calibrate $\lambda_{P}$ accordingly in ourm odel. $T$ he new ranking obtained from the new set of sim ulations show no im portant di erence, except for the national dem and solution which becom es less e cient in stabilizing the credit-to-gdp ratio. W e also investigate the im plication of asym m etric steady state leverages of firm $s$ and of banks between countries. Core countries observed a lower net-w orth to asget ratio than Peripheral econom ies for firm $\mathrm{s}^{32}$ we take this feature into account by calibrating $\bar{N}_{\mathrm{p}} / \overline{\mathrm{K}}_{\mathrm{p}}$ at $20 \%$ as in Italy. For banks, we use the ECB 'S R isk A ssessm ent Indicators (RA I) and find that Core banks are less capitalized on average, in particular because of B elgium , G erm any and N etherlands's low equity to assets ratios. W e calibrate the leverage ratio of core banks to $6 \%$ to incomporate this structural asym m etry and nun the sim ulations. W e observe no clear ranking change under these two asym m etries.

\footnotetext{
${ }^{32}$ There is a clear asymmetry between Core and Peripheral countries in terms of debt-to-financial assets ratios. For instance, France had a ratio of $40 \%$, Germany $60 \%$ and Netherlands $60 \%$ while Italy had $80 \%$ and Spain $60 \%$.
} 
O verall, these robustness exercises confirm that these structural aspects does not a ect the ranking as second order statistics $m$ in $m$ ized in the loss function are rather independent of structural asym m etries.

6. Conchusion

This paper shows that intemational lending flows have $m$ ixed e ects on the optim al conduct of $m$ acroprudential policy in the Eurozone. Contrasting altemative nules for countercyclical capital bu ers, our results suggest that targeting a national credit-to-gdp ratio should be favored to federal averages as this nule induces better stabilizing perform ances in term sofoutput and loan volatility. The im portant divergences in credit cycles between core and peripheral countries reported in the data require a national orientation of $\mathrm{m}$ acropnudentialpolicy taibred to dom estic financial developm ents. Our results have also underlined the reduced interest of lifting up $m$ acroprudential policym aking to the supra-national level. Indeed, national capital bu ers reacting to the union-w ide loan-to-G D P ratio lead to the sam e stabilization results than the one obtained under the national reaction when $m$ utual crosstborder lending reaches $45 \%$. H ow ever, even if cross-border linkages are high enough to justify the im plem entation of a federaladjusted solution, the reaction to nationallending conditions rem arkably rem ains optm al. In addition, we find that adjusting the $m$ acroprudential instrum ent to capital nflows is a prom ising tool for countries experiencing loans inflow s.

The analysis of crosstoorder lending on the conduct of $\mathrm{m}$ acropnudential policy is a burgeoning research area. In thispaperwe focused on countercyclicalcapitalbu ers, and an interesting question for future research is to evaluate how this result favoring self-oriented $m$ acroprudential $m$ easures $m$ ay be a ected by the choice of altemative $m$ acroprudential instrum ents. The construction of an originalw elfare index, that features a trade-o between $m$ acroeconom ic and financial stability, could be a next step of research. F inally, the analysis of the C CB rate through a R am sey allocation problem could also be part of a future research agenda. 
A cknow ledgm ents

W e are very grateful to the editors and three anonym ous referees for their helpful com $m$ ents that helped us to im prove significantly the paper. W e thank Taryk Bennani, Am brogio C esa B ianchi, Jean B emard Chatelain, Laurent C lerc, Patridk Fève, Julien Idier, Christo er K ok, John Lew is, P ier Lopez, M arco R atto, K arlW alentin and R afW outers for their com $m$ ents. W e are grateful to Johannes $P$ feifer for providing codes for optm alpolicy nules $w$ ith restrictions. W e thank Jean-P ierre A llegret, M anuel M ota Frefitas M artins and Tovonony R azafindrabe for their discussions as well as participants at the conference in Intemational $\mathrm{M}$ acroeconom ics in Paris, the Conference in Com putational Econom ics, the Intemationalsym posium in $M$ oney $C$ redit and B anking in Lyon, the French $E$ conom ic A Ssociation annualm eeting in Lyon and sem inars at the B ank of England and the B anque de France. This paper was w ritten while $\mathrm{G}$ authier Verm andel wâs w orking for European Central B ank, D G M acropnudential Policy and F inancial Stability, M acro-F inancial Linkages $\mathrm{D}$ ivision. $\mathrm{W}$ e rem ain responsible for any emors and om issions.

A ppendix A. D ata sources

G ross dom estic product: m ilijons of national currency, current prices, quarterly levels, seasonally adjusted - sources Eurostat. P rivate final consum ption expenditure: m illions of national currency, current prices, quarterly levels, seasonally adjusted - sources Eurostat. G ross fixed capital form ation : m illions of national currency, current prices, quarterly levels, seasonally adjusted - sources Eurostat. G D P deflator: D eseasonalized using a m ultiplicative decom position - sources Eurostat. Loans to N on -F inancial corporations: Index of $\mathrm{N}$ otional Stocks, Total m aturity, Euro area (changing com position) counterpart, D eseasonalized using a m ultiplicative decom position, m onthly data (aggregated to get quarterly data) - sources ECB (internal backcasted series). Loans to M F Is: Index of N otional Stocks, Totalm aturity, Euro area (changing com position) counterpart, D eseasonalized using a $m$ ultiplicative decom position, $m$ onthly data (aggregated to get quarterly data) - sources ECB (internal backcasted series). B orrow ing cost: m onthly (taken in average to get quarterly data), C redit and other institutions (M F I except M M F s and 
central banks); Loans up to 1 year; BS counterpart sector: $N$ on-F inancial conporations (S.11); O utstanding am ount - sources ECB (internal backcasted series). D eposit rate: $m$ onthly (taken in average to get quarterly data), $\mathrm{F}$ im $\mathrm{s}$ and $\mathrm{H}$ ouseholds; - sources ECB (internal backcasted series). M oney $m$ arket rates: $m$ oney $m$ arket interest rates, one year m aturity, quarterly data - sources Eurostat .

A ppendix B. The non-banking part of the m odel

W e extend the m odel of Poutineau and Verm andel (2015) to account for the conduct of $m$ acropnudential policy in an heterogenous m onetary union such as the Euro A rea. O ur m odel describes a m onetary union $m$ ade of two asym m etric countries $i \quad\{c, p\}$ (where $c$ is for core and $p$ for periphery). Each part $i$ of the m onetary union is of a relative size $\mathrm{n}_{\mathrm{i}}{ }^{33}$ A s shown in F igure 2, each country is populated by consum ers, interm ediate and final producers, entrepreneurs, capital suppliers and a banking system . R egarding the conduct ofm acroeconom ic policy, we assum e nationalfiscal authorities and a com m on centralbank. The im plem entation of the m acroprudentialpolicy is left open, and w ill be discussed below in another section. O urm odel is confronted to the data using B ayesian econom etrics and it encom passes several sources of rigidities to enhance its em pirical relevance. The set of real rigidities accounts for consum ption habits, investm ent adjustm ent costs and loan dem and habits. Regarding nom inal rigidities, we account for stidkiness in final goods prices and loan interest rates.

Appendix B.1. Households and labor unions

The preferences of the $\mathrm{j}^{\text {th }}$ household are given by:

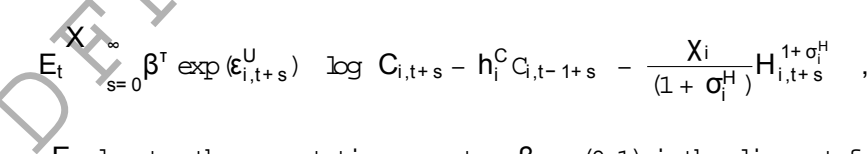

where $\mathrm{E}_{\mathrm{t}}$ denotes the expectation operator, $\beta \quad(0,1)$ is the discount factor, param eter $\sigma_{i}^{H}>0$ shapes the utility function of the $j^{\text {th }}$ household associated to hours worked $H_{i, t}$.

\footnotetext{
${ }^{33}$ Normalizing the size of the monetary union to unity, the relative size of the core are is $\mathrm{n}$ and the relative size of the peripheral area is $1-n$.
} 
The consum ption index $C_{i, t}$ is subject to extemal habits $w$ ith degree $h_{i}^{C} \quad[0 ; 1)$ w ith $C_{i, t-1}$ the aggregate lagged consum ption, while $X_{i}>0$ is a shift param eter allow ing us to pin down the steady state am ount of hours worked. The discount factor is a ected by a tim epreference shock $\varepsilon_{i, t}^{U}$ follow ing an AR (1) stochastic process that exogenously changes the household's intertem poral allocation of consum ption over the cycle.

H ousehold $\mathrm{j}^{\text {th }}$ period budget constraint is given by:

$$
w_{i, t}^{h} H_{i, t}+D_{i, t-1}^{d} \frac{1+R_{i, t-1}^{D}}{\left(1+\pi_{i, t}^{C}\right)}+i, t=C_{i, t}+D_{i, t}^{d}+t_{i, t}+p_{i, t} A C_{i, t}^{D} .
$$

The incom e of the representative household is $m$ ade of labor incom $\mathrm{w}$ ith the desired real wage $\mathrm{w}_{\mathrm{i}, \mathrm{t}}^{\mathrm{h}}$, interest paym ents for deposit services $\mathrm{D}_{\mathrm{i}, \mathrm{t}}^{\mathrm{d}}$ and real eamings $\mathrm{i}, \mathrm{t}$ from shareholdings of firm s and unions. The interest rate is deflated by the consum er price inflation rate $1+\Pi_{i, t}^{C}=P_{i, t}^{C} / P_{i, t-1}^{C}$. The representative household spends this incom e on consum ption, deposits and tax paym ents for a realam ount of $\mathrm{t}_{\mathrm{i}, \mathrm{t}}$. Finally, we assum $e$ that the household has to pay quadratic adjustm ent costs to buy new deposits, ${ }^{35}$ these costs are paid in term s hom e goods $w$ ith relative price $p_{i, t}=P_{i, t} / P_{i, t}^{C}$ where $P_{i, t}$ is the production price index of hom e produced goods while $P_{i, t}^{C}$ is the consum ption price index. H ouseholds consum e both hom e and foreign goods and their corresponding consum ption basket follow s a standard CES function:

$$
C_{i, t}=1-\alpha_{i}^{C} C^{1 / \mu} C_{h i, t}^{(\mu-1) / \mu}+\alpha_{i}^{C}{ }^{1 / \mu} C_{f i, t}^{(\mu-1) / \mu}{ }^{\mu /(\mu-1)},
$$

where param eter $\mu>0$ is the elasticity of substitution betw een dom estic and foreign final goods and $\alpha_{i}^{C}[0,1 / 2] m$ easures the fraction of goods bought abroad. The comresponding price index is, $P_{i, t}^{C}=\left(1-\alpha_{i}^{C} P_{h, t}^{1-\mu}+\alpha_{i}^{C} P_{f, t}^{1-\mu}\right)^{1 /(1-\mu)}$.

Houscholds delegate the wage negotiation process to unions. H ouseholds provide dif-

${ }^{34} \mathrm{As}$ explained below, the desired wage is negotiated by a trade union.

${ }^{35}$ This cost is almost neutral on the dynamic of the model and is necessary to remove an unit root component which is standardly induced by the international nature of our model. See Schmitt-Grohé and Uribe (2003) for an extensive discussion and solutions regarding this issue. The functional form we choose is: $A C_{i, t}^{D}(j)=0.5 X_{D}\left(D_{i, t}^{d}(j)-\bar{D}_{i}\right)^{2} / \bar{D}_{i}$, where $\bar{D}_{i}$ is the steady state level of deposits and $X_{D}>0$ is the cost parameter. 
ferentiated labor types, sold by labor unions to perfectly com petitive labor packers who assem ble them in a CES aggregator and sell the hom ogenous labor to interm ediate firm $\mathrm{s}^{36}$ U nions negotiate the real $\mathrm{m}$ argin between the real desired wage of households $\mathrm{w}_{\mathrm{i}, \mathrm{t}}^{\mathrm{h}}$ and the realm arginal product of labor $W_{i, t} / P_{i, t}^{C}$. U sing a $C$ alvo wage nom inal rigidity device, each period a random fraction $\theta_{1}^{\mathrm{W}}$ of unions is unable to re-negotiate a new wage. Assum ing that the trade union is able to m odify its wage $w$ ith a probability $1-\theta_{1}^{w}$, the $j{ }^{\text {th }}$ union chooses the nom inaloptim al wage $W_{i, t}^{*}$ to $m$ axim ize its expected sum of profits:

$$
E_{t}^{X}{ }_{s=0}^{X} \theta_{i}^{W s}{ }_{i, t+s} \frac{W_{i, t}^{*}}{P_{i, t+\tau}^{C}}{ }_{k=1}^{C} 1+\pi_{i, t+k-1}^{c} \xi_{i}^{W}-\exp \left(\varepsilon_{i, t+s}^{W}\right) W_{i, t+s}^{h} H_{i, t+s}
$$

where $i, t+\tau$ is household's stochastic discount factor, $\varepsilon_{i, t}^{\mathrm{W}}$ is an ad-hoc wage-push shock to the real w age equation follow ing an A R (1) process w hich captures exogenousfluctuations in the wage $m$ argin negotiated by unions and a ects in tum the productivity of the econom $y$.

\section{Appendix B.2. Firms}

Interm ediate firm s produce di erentiated goods, decide on labor and capital inputs on a perfectly com petitive inputs $m$ arket and set prices according to the $C$ alvo $m$ odel $T$ he $i^{\text {th }}$ firm has the follow ing Cobb-D ouglas technology:

$$
Y_{i, t}=\exp \left(\varepsilon_{i, t}^{A}\right) K_{i, t}^{u} \hat{H}_{i, t}^{d} 1<a
$$

where $Y_{i, t}$ is the standard production function that com bines (utilized) physicalcapitalK $\mathrm{i}_{i, t}^{u}$ labor dem and $H_{i, t}^{d}$ to household and (exogenous) technology $\varepsilon_{i, t}^{A}$. Interm ediate firm s solve a two-stage problem. In the first stage, taking the real input prices $\mathbf{w}_{\mathrm{i}, \mathrm{t}}$ and $\mathrm{z}_{\mathrm{i}, \mathrm{t}}$ as given, firm s rent inputs $\mathrm{H}_{\mathrm{i}, \mathrm{t}}^{\mathrm{d}}$ and $\mathrm{K}_{\mathrm{i}, \mathrm{t}}^{\mathrm{u}}$ in a perfectly com petitive factorm arket in order to $\mathrm{m}$ in $\mathrm{m}$ ize costs subject to the production constraint (B .5) to determ ine the realm arginal cost ma,t .

\footnotetext{
${ }^{36}$ Labor packers are perfectly competitive and maximize profits, $W_{i, t} H_{i, t}^{d}-G\left(W_{i, t}(j) H_{i, t}(j)\right)$, under their packing technology constraint, $H_{i, t}=\left[\left(1 / n_{i}\right)^{1 / w} G\left(H_{i, t}(j)^{(w-1) / w}\right)\right] w /(w-1)$. Here, $W_{i, t}$ is the production price, $\mathrm{H}_{\mathrm{i}, \mathrm{d}}^{\mathrm{d}}$ is the labor demand and $\mathrm{w}$ is a substitution parameter. The first order condition which determines the optimal demand for the $j^{\text {th }}$ labor type is, $H_{i, t}(j)=\left(1 / n_{i}\right)\left(W_{i, t}(j) / W_{i, t}\right)^{-} w^{w} H_{i, t}^{d}, j$. Thus the aggregate wage index of all labor types in the economy emerges from the zero-profit condition: $W_{i, t}=\left[\left(1 / n_{i}\right) G\left(W_{i, t}(j)^{1-w}\right)\right]^{1 /(1-w)}$
} 
In the second-stage, the interm ediate firm i setsprices according to a C alvo m echanism . Each period firm $i$ is not allowed to re-optim ize its price w ith probability $\theta_{1}^{P}$ but price increases by $\xi_{i}^{P} \quad[0 ; 1)$ w th respect to the previous period's rate of price inflation, $P_{i, t}=$ $\left(1+\pi_{i, t-1}\right)^{\xi_{i}^{P}} P_{i, t-1}$. The $i^{\text {th }}$ firm allow ed to m odify its selling price $w$ ith a probability $1-\theta_{1}^{P}$ chooses $\mathrm{P}_{\mathrm{i}, \mathrm{t}}^{*}$ to $\mathrm{m}$ axim ize its discounted sum of profits:

$$
E_{t}^{X}{ }_{s=0}^{\infty} \theta_{i}^{P s} i_{i, t+s} \frac{P_{i, t}^{*}}{P_{i, t+s}^{C} C^{C}=1}\left(1+\pi_{i, t+k-1}\right)^{\xi_{i}^{P}}-\exp \left(\varepsilon_{i, t+s}^{P}\right) m c_{i, t+s} Y_{i, t+s} \text { (B .6) }
$$

where $\varepsilon_{i, t}^{P}$ is an ad-hoc cost-push shock to the inflation equation follow ing an A R (1) process which captures exogenous inflation pressures.

O nce goods are produced and prices are set, final firm's act as goods packers: they com bine di erentiated goods to produce the hom ogenous final good sold m ainly to households. ${ }^{37}$

\section{Appendix B.3. Entrepreneurs}

The capital required by the interm ediate firm in the production process is financed by an entrepreneur that belongs to the sam e business unit $i$. The balance sheet of the $i^{\text {th }}$ entrepreneur is given by:

$$
q_{i, t} K_{i, t}=L_{i, t}^{H}+N_{i, t}
$$

D efining $Q_{i, t} K_{i, t}$ as the amount of capital to be financed by entrepreneuri , $q_{i, t}=Q_{i, t} / P_{i, t}^{C}$ is the real shadow value of capitalgoods. This quantity $\mathrm{q}_{\mathrm{t}, \mathrm{K}} \mathrm{K}_{\mathrm{i}, \mathrm{t}}$ isfinanced by the entrepreneur through two m eans: its net wealth $\mathrm{N}_{\mathrm{i}, \mathrm{t}}$ and the real am ount borrowed from the banking system, $\mathrm{L}_{i, t+1}^{H}$. Form ally, ban dem ands are subject to extemal habits as follow s: $L_{i, t}^{H}=$ $L_{i, f}^{d}-h_{i}^{L}\left(L_{i, t-1}^{d}-L_{i}^{d}\right)$ with the habit degree $h_{i}^{L} \quad[0,1), L_{i, t-1}^{d}$ the aggregate average level of

${ }^{37}$ Goods packers are perfectly competitive and maximize profits, $P_{i, t} Y_{i, t}^{d}-G\left(P_{i, t}(i) Y_{i, t}(i)\right)$, under their packing technology constraint, $Y_{i, t}^{d}=\left[\left(1 / n_{i}\right)^{1 / p} G_{(}\left(Y_{i, t}(i)^{(p-1) / p}\right)\right]^{p /(p-1)}$. Here, $P_{i, t}$ is the production price, $Y_{i, t}^{d}$ is the aggregate demand (or the resource constraint) and $P$ is a substitution parameter. The first order condition which determines the optimal demand for the $i^{\text {th }}$ good is, $Y_{i, t}(i)=$ $\left(1 / n_{i}\right)\left(P_{i, t}(i) / P_{i, t}\right)^{-} P Y_{i, t}^{d}$, i. Thus the aggregate price index of all varieties in the economy emerges from the zero-profit condition: $P_{i, t}=\left[\left(1 / n_{i}\right) G\left(P_{i, t}(i)^{1-p}\right)\right]^{1 /(1-p)}$. 
loans of the previous period and $L_{i}^{d}$ the steady state stock of loans. ${ }^{38}$ Em pirically, firm s and banks operating in the Euro A rea choose longer debt $m$ aturities than the standard oneperiod contract usually used in real business cycle m odels. Then the term $h_{i}^{L} L_{i, t-1}^{d}$ allows for slow adjustm ent over tim e of the balance sheet constraint, to capture the idea that in practice borrow ers do not readjust their outstanding am ount of loans every quarter. This approach of introducing slow adjustm ent of credit is close to Iacoviello (2015), em ployed here in a context of a financial accelerator m odel. D uring phases of recession characterized by asset price collapses of $q_{, t}$, this friction prevents the total stodk of loans to fall at the sam e rate as the price of financial assets, thus $m$ aking credit less procyclical consistently w ith em pirical evidence. Since these habits don't directly a ect the first order condition of the entrepreneur (as the overall problem of the entrepreneur can be expressed in term $\mathrm{s}$ of physical capital directly), their im plications on entrepreneurs' profits is rather $m$ inor but large for financial interm ediary facing a persistent dem and for bans.

To introduce conporate cross-border lending, we follow Poutineau and Verm andel (2015) and B rzoza.B rzezina et al. (2015) by adopting a CES function that bundles dom estic and foreign loans o ered by banks operating in the m onetary union $3^{39}$

$$
L_{i, t}^{d}=1-\alpha_{i}^{L}{ }^{1 / u} L_{h i, t}^{d}(u-1) / y+\alpha_{i}^{L}{ }^{1 / u} L_{f i, t}^{d}(u-1) / u U /(u-1) .
$$

Here, param eter $U$ is the elasticity of substitution between dom estic and foreign interbank funds, $a_{i}^{L} \quad[0,1 / 2]$ represents the percentage of cross-border interbank loan flow s in the m onetary union and $L_{h i, t}^{d}$ (resp. $L_{f i, t}^{d}$ ) the am ount of dom estic (resp. foreign) loans dem anded by borrow ing entrepreneurs living in country i. A s a consequence, the bor-

\footnotetext{
${ }^{38}$ In the estimation exercise, we use the total stock of loans, they are of different maturities implying a strong autocorrelation. Simply by introducing loan demand habits, taking into account the high autocorrelation of loans becomes tractable easily and does not change the st eady state of the model. For instance in 1999, loans with a maturity above one year represented $64 \%$ of the outstanding stock of loans in the Eurosystem.

${ }^{39} \mathrm{Kollmann}$ et al. (2011) provides a complementary way of introducing cross-border lending through global banks. However, this approach assumes a perfect credit market intregration between Euro participants that is not consistent with the data. Alternatively, Dedola and Lombardo (2012) introduce cross-border loans through a portfolio problem that requires a second order approximation to the policy function, which poses an issue when putting the model to the data.
} 
row ing cost is a CES aggregate of hom e and foreign credit rates defined as: $1+\mathrm{P}_{\mathrm{i}, \mathrm{t}}^{\mathrm{L}}=$ $\left(\left(1-\alpha_{i}^{L}\right)\left(1+R_{h, t}^{L}\right)^{1-u}+\alpha_{i}^{L}\left(1+R_{f, t}^{L}\right)^{1-u}\right)^{1 /(1-u)}$.

$R$ egarding financial frictions, we reintempret the financial accelerator à la Bemanke et al (1999) from a banking perspective in order to have state-contingent lending rates needed to introduce $m$ acropnudentialm easures. ${ }^{40}$ To do so, we follow the m odelling device of Poutineau and Verm andel (2015) that provides a m icro-foundation for the financial acceleratorm echanism relying on biased expectations of entrepreneurs instead of a standard m oral hazard problem. The investm ent projects undertaken by the entrepreneur are risky and di erw ith respect to their individual retums. To m odelindividualriskiness, w e borrow from Bemanke et al. (1999) and assum e that each project has an individual retum equal to $\omega 1+R_{i, t}^{k}$, i.e. that the aggregate retum of investm ent projects in the econom y $1+R_{i, t}^{k}$ is $m$ ultiplied by a random value $\omega$. The representative entrepreneur conducts a $m$ ass $\omega$ of diversified investm ent projects and the profit of the $\omega^{\text {th }}$ investm ent project is given by:

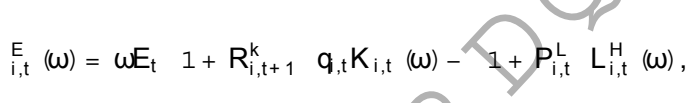

In order to acquire a loan, entrepreneurs have to engage in a financial contract before the realization of $\omega .{ }^{41}$ A fter engaging in the financial contract, entrepreneurs recognize ex post the value of $\omega_{, t}^{C}$ which separates the default space $\left(\omega<\omega_{, t}^{C}\right)$ from the space of gains $\left(\begin{array}{ll}\omega & \omega_{, t}^{c}\end{array}\right)$. Thereby the ex post threshold separating the default space from the profitable space is com puted trough the zero profit condition on Equation B .9:

$\omega_{i, t}^{C} 1+R_{i, t}^{k} q_{t, t-1} K_{i, t-1}=1+P_{i, t-1}^{L} L_{i, t-1}^{H}$.

Follow ing H elpm an et al (2004), we adapt the Pareto distribution to m odel the pro-

\footnotetext{
${ }^{40}$ The pathbreaking contribution of Bernanke et al. (1999) focuses on the demand side of credit market through a moral hazard problem but neglects its supply side and in turn the possibility to introduce macroprudential measures that could affect the macroeconomic outcome. Their model is closed assuming that lending rates are pre-determined.

${ }^{41}$ The individual return $\omega$ is al so referred as an idiosyncratic shock in the financial accelerator literature. The debt contract is conclude before the idiosyncratic shock is recognized which generates unexpected losses for the entrepreneurs and lenders.
} 
ductivity of firm s in a financial context. Investm ent projects are drawn from a Pareto distribution $\omega \quad P(K)$ w ith support $\left.\omega \quad \omega_{\min },+\quad\right)$ where $K>1$ is the shape param eter and $\omega_{\min }>0$ is the low er bound of the distribution. G iven the characteristics of the distribution, it is possible to com pute the share of profitable projects, denoted $\eta_{\mathrm{i}, \mathrm{t}}^{\mathrm{E}}=\left(\omega_{\min } / \omega_{, \mathrm{t}}^{\mathrm{C}}\right)^{\mathrm{K}}$, and their aggregate value, $\bar{\omega}_{, t}=\mathrm{K} /(\mathrm{K}-1) \omega_{, t}^{\mathrm{c}} \cdot{ }^{42} \mathrm{~W}$ hen the entrepreneur is underw ater $\mathrm{w}$ ith an investm ent project value below the cost of credit, she endogenously defaults on her loan and abandons her investm ent project.

To introduce a financial accelerator m echanism, we assum e that entrepreneurs have short term distorted expectations regarding the aggregate profitability of their aggregate investm ent projects $\bar{\omega}_{, t}$, thus creating a financial friction in the econom $y$ w ith dynam ic properties close to B emanke et al. (1999). The perceived ex ante value of profitable projects $\bar{\omega}_{, t+1}$ is defined by the CES function: $:^{4}$

$$
g\left(\bar{\omega}_{, t+1}\right)=\bar{\omega}^{1 /\left(1-\kappa_{i}\right)}\left(\bar{G}_{, t+1}\right)^{k_{i} /\left(k_{i}-1\right)}
$$

where $\mathrm{K}_{\mathrm{i}}[0,1)$ is the elasticity of the extemalfinance prem ium and $\bar{\omega}$ is the steady state of $\bar{\omega}_{, t+1}$. D uring phases of expansion characterized by high aggregate retums above the the steady state $\bar{\omega}_{, t+1}>\bar{\omega}$, entrepreneurs' forecasts regarding the aggregate profitability are optim istic $w$ ith $g\left(\bar{\omega}_{, t+1}\right)>\bar{\omega}_{t+1}$. In contrast for low expected realizations of $\bar{\omega}_{, t+1}$ below its steady state, entrepreneurs tend to hold pessim istic expectations about their retums $w$ ith $g\left(\bar{\omega}_{, t+1}\right)<\bar{\omega}_{, t+1}$. F inally in steady state, there is no expectation bias, $g(\bar{\omega})=\bar{\omega} \cdot{ }^{44}$ Every

$$
<\text {. }
$$

\footnotetext{
${ }^{42}$ Using the characteristics of the Pareto distribution $F(\omega)$, the distribution of stochastic investment projects $\omega$ has a positive support, is independently distributed (across entrepreneurs and time) with unitary mean $E[\omega]=1$, and density function $f(\omega)$. Investment projects above the cut-off value, $\omega>\omega_{1, t}^{c}$, have positive profits $\Pi_{i, t}^{E}(\omega) \quad 0$ which allows entrepreneurs to repay its loans to the bank. The share of profitable projects $1-F(\omega)$ is computed as, $\eta^{E}=\operatorname{Pr} \omega \omega^{C}={ }_{\omega^{C}} f(\omega) d \omega=R_{\infty}\left(\omega_{\min } / \omega^{C}\right)^{K}$ while the conditional expectation of $\omega$ when entrepreneur's project is gainful is, $\eta^{E} \bar{\omega}={ }_{\omega^{C}}$ wf $(\omega) d \omega$ with $\bar{\omega}=E \omega \omega \quad \omega^{C}=\frac{k}{k-1} \omega^{C}$.

${ }^{43}$ There is a rich literature providing evidence that entrepreneurs are more optimistic compared to the general population; for some recent studies see, e.g., Landier and Thesmar (2009), Puri and Robinson (2013), Dawson and Henley (2013).

${ }^{44}$ It is important to stress that function $g\left(\bar{\omega}_{, t+1}\right)$ only affects expected returns of $E_{t}\left\{\bar{w}_{, t+1}\right\}$, while for ex post values (e.g., $\bar{w}_{, t}$ and $\bar{w}_{, t-1}$ ) the entrepreneur recorgnizes the true value of her return.
} 
shodk driving financial retums above or below the steady state $w$ ill trigger an acceleration of the business cycles through these biased expectations for $\mathrm{K}_{\mathrm{i}}>0$.

A ggregating all profitable investm ent projects (ie. above $\omega_{, t}^{C}$ ) that the entrepreneur does not abandon, it chooses a capital value of $\mathrm{K}_{\mathrm{i}, \mathrm{t}}$ that $\mathrm{m}$ axim izes its profit (before the realization of $\omega$ ) defined as:

$$
\mathrm{i}_{\mathrm{i}, \mathrm{t}}^{\mathrm{E}}=\mathrm{E}_{\mathrm{t}} \eta_{\mathrm{i}, \mathrm{t}+1}^{\mathrm{E}} \mathrm{g}\left(\bar{\omega}_{\mathrm{t}, \mathrm{t}+1}\right) 1+\mathrm{R}_{\mathrm{i}, \mathrm{t}+1}^{\mathrm{k}} \mathrm{q}_{\mathrm{i}, \mathrm{t}} \mathrm{K}_{\mathrm{i}, \mathrm{t}}-1+\mathrm{P}_{\mathrm{i}, \mathrm{t}}^{\mathrm{L}} \mathrm{L}_{\mathrm{i}, \mathrm{t}}^{\mathrm{H}} . \mathrm{C}_{(\mathrm{B})}
$$

Taking the first order condition com bined w ith Equation B.10, the financial accelerator principle em erges through the extemalfinance prem ium expression:

$$
\frac{1+R_{i, t+1}^{k}}{1+P_{i, t}^{L}}=\frac{1}{\bar{\omega}} \frac{K}{K-1} 1-\frac{N_{i, t}}{q_{, t} K_{i, t}}{ }^{K_{i}}
$$

Up to a first order, $r_{i, t+1}^{k}-\hat{p}_{i, t}^{L} \quad K_{i}\left(\hat{q}_{, t}+\hat{k}_{i, t}-\hat{n}_{i, t}\right)$, the spread is a positive function to the capital-to-net wealth ratio. Under this assum ption, the balance sheet of bomrow ers a ects the borrow ing conditions and $m$ agnifies the financial cycle. The size of the accelerator is determ ined by the degree of bias $\mathrm{K}_{\mathrm{i}}$ of bonrow ers.

$\mathrm{F}$ inally, the law of $\mathrm{m}$ otion of the net wealth is given by profit obtained at the end of period $t-1$ :

$$
N_{i, t}=1-\delta^{E} \underset{i, t-1}{E} \exp \left(\varepsilon_{i, t}^{N}\right)
$$

where $\delta^{E} \quad[0,1]$ is the net wealth decay that is related to the default rate of entrepreneur (endogenously determ ined in steady state) and $\varepsilon_{i, t}^{N}$ is an AR (1) shodk to the net wealth of entrepreneurs which captures exogenous variations in stock prices and the dem and for loans.

\section{Appendix B.4. Capital goods producers}

The capital producer rents and refurbishes the capital stodk used by interm ediate firm s and financed by the entrepreneurs on a com petitive $m$ arket. The law of $m$ otion of physical 
capital is determ ined by:

$$
K_{i, t}=1-S\left(\left(\exp \left(\varepsilon_{i, t}^{l}\right) I_{i, t} / I_{i, t-1}\right) I_{i, t}+(1-\delta) K_{i, t-1},\right.
$$

where $\varepsilon_{i, t}^{1}$ is a stochastic process which captures exogenous changes in asset price fluctuations and the adjustm ent cost function taken from Sm ets and $W$ outers (2007) reads as: $S\left(X_{t}\right)=X_{i}^{1}\left(X_{t}-1\right)^{2} w$ ith $X_{i}^{1} \quad 0$ is the adjustm ent cost. In addition, investm ent is com posed of dom estic and foreign goods sum m arized by a CES function:

$$
I_{i, t}=\left(1-\alpha_{i}^{1}{ }^{1 / \mu} I_{h i, t}^{(\mu-1) / \mu}+\alpha_{i}^{1 / \mu} I_{f i, t}^{(\mu-1) / \mu}\right)^{\mu /(\mu-1)},
$$

where param eter $\mu$ is the elasticity of substitution between dom estic and foreign goods in investm ent and $\alpha_{i}^{1} m$ easures the degree of investm ent diversification in the monetary union between hom e and foreign countries. The oorresponding price index of investm ent is, $P_{i, t}^{l}=\left(1-a_{i}^{l}\left(P_{h, t}\right)^{1-\mu}+\alpha_{i}^{l}\left(P_{f, t}\right)^{1-\mu}\right)^{1 /(1-\mu)}$.

The representative capital supplier chooses $\mathrm{l}_{\mathrm{i}, t}$ to $\mathrm{m}$ axim ize its real discounted profits:

$$
\max _{\left\{I_{i, t}\right\}} E_{t}^{X}{ }_{s=0} i, t+s \quad q_{t, t+s} 1-s\left(\exp \left(\varepsilon_{i, t}^{1}\right) l_{i, t} / l_{i, t-1}\right)-p_{i, t+s}^{l} I_{i, t+s},
$$

whereq $q_{, t}=Q_{i, t} / P_{i, t}^{C}$ stands for the real shadow value of investm ent goods and $p_{i, t}^{1}=P_{i, t}^{1} / P_{i, t}^{c}$ is the relative price of investm ent goods.

Finally regarding capital utilization, the optm al rate of utilization is given by ${ }^{45}$

$$
a^{0}\left(u_{i, t}\right)=Z_{i, t}, \quad w \text { ith } a\left(u_{i, t}\right)=\bar{Z}\left(u_{i, t}-1\right)+0.5 \psi_{i} /\left(1-\psi_{i}\right) \bar{Z}\left(u_{i, t}-1\right)^{2}, \quad \text { (B . 18) }
$$

where $\psi_{i} \quad(0,1)$ is the elasticity of utilization costs $w$ ith respect to capital inputs. As in Smets and $W$ outers $(2003,2007)$, capital requires one period to be settled so that utilized capital is defined as, $\mathrm{K}_{\mathrm{i}, \mathrm{t}}^{\mathrm{u}}=\mathrm{u}_{\mathrm{i}, \mathrm{t}} \mathrm{K}_{\mathrm{i}, \mathrm{t}-1}$.

\footnotetext{
${ }^{45}$ When households do not take capital supply decisions, the optimal capital utilization is determined by, $\max _{u_{i, t}}\left(Z_{i, t} u_{i, t}-a\left(u_{i, t}\right)\right) K_{i, t}$.
} 


\section{Appendix B.5. Monetary and fiscal policy}

$\mathrm{N}$ ational govemm ents finance public spending by charging lum $\mathrm{p}$-sum taxes to households $t_{i, t}$. The total am ount of taxes finance public spending w ithout contracting public debt such that the public budget is always balanced. As in Sm ets and W outers (2003, 2007), the level of spending $G_{i, t}$ is exogenously determ ined as a constant fraction of output $g \bar{Y} \exp \left(\varepsilon_{i, t}^{G}\right)$, where $g \bar{Y}$ is the fix com ponent and $\varepsilon_{i, t}^{G}$ is the tim e-varying com ponent of spending that follow s a standard A R (1) shodk process. Param eter g $[0,1)$ is the steady state spending-to-G D P ratio. It is im portant to m ention that we om it seigniorage revenues that could be given to fiscal authorities as their inclusion generates an explosive path of deposits. ${ }^{46}$ This could be a lim itation of our m odel, how ever Leeper (1991) indicates seigniorage represents a sm all fraction of govemm ent revenues for developed econom ies thus show ing that its om ission does not seem to be im portant for the analysis conducted here.

Conceming federal m onetary policy, the general expression of the interest nule im plem ented by the m onetary union central bank follow s the linear nule:

$$
R_{t}-\bar{R}=\rho R_{t-1}-\bar{R}+(1-\rho)\left(\varphi^{\pi} \pi_{t}^{C}+\varphi^{\Delta y}\left(Y_{t}-Y_{t-1}\right)\right)+\varepsilon_{t}^{R},
$$

where $\varepsilon_{t}^{R}$ is a m onetary policy shodk com $m$ on to the m onetary union $m$ em bers, $\varphi^{\pi} \quad 1$ is the inflation target param eter, $\varphi^{\wedge y}$ is the GD P grow th target. A s m onetary policy responds to the aggregate evolution of inflation and activity in the monetary union, recall that $\pi_{t}^{c}=n_{c} \Pi_{c, t}^{C}+n_{p} \Pi_{p, t}^{c}$ and $Y_{t}=n_{c} Y_{c, t}+n_{p} Y_{p, t}$.

\section{Appendix B.6. Stochastic shock processes}

To be in ine with the benchm ark m odel of Sm ets and W outers (2003) for the Euro A rea, allour random processes follow s an AR (1) specification. Each part of the Eurozone inchades 10 country-specific shocks for $S=\{A, G, U, I, P, W, N, D, B, L\}$ such that:

$$
\varepsilon_{i, t}^{s}=\rho_{i}^{s} \varepsilon_{i, t-1}^{s}+\eta_{i, t}^{s} w \text { ith } \eta_{i, t}^{s} \quad N\left(0, \sigma_{i}^{s}\right) .
$$

\footnotetext{
${ }^{46} \mathrm{~T}$ his assumption is common for recent macroeconomic models as underlined by Curdia and Woodford (2011). We refer to Gerali et al. (2010) or Adam (2011) for macro-models without seignioriage.
} 
F inally both part of the $m$ onetary union are a ected by a com $m$ on $m$ onetary policy shock in Equation $B .19$ defined as, $\varepsilon_{t}^{R}=\rho^{R} \varepsilon_{t-1}^{R}+\eta_{t}^{R} w$ ith $\eta_{t}^{R} \quad N\left(0, \sigma^{R}\right)$. M arkups shodks for $\mathrm{m}=\{\mathrm{P}, \mathrm{W}, \mathrm{D}\}$ are norm alized to one, as im plicitly assum ed in Sm ets and $\mathrm{W}$ outers (2003), by dividing their stochastic innovations $\eta_{i t}^{m}$ by the elasticity of the linear $N$ ew Keynesian Phillips curve, $\left(1-\beta \theta_{1}^{m}\right)\left(1-\theta_{1}^{m}\right) / \theta_{1}^{m}$.

\section{Appendix B.7. Aggregation and market clearing}

The general equilibrium of the $\mathrm{m}$ odel is set as follow s. A fter (i) aggregating all agents and varieties in the econom $y$, (ii ) im posing $m$ arket clearing for allm arkets, (iii) substituting the relevant dem and functions, (iv) norm alizing the total size of the m onetary union $\left(n_{c}+\right.$ $n_{p}=1$ ) such that the size of the core area is $n$ and the peripheral area size is $1-n$, we get the general equilibrium conditions of the $m$ odel. $w$ e can express the aggregation function of variable $X_{t}(x)$ as: $G\left(X_{i, t}(x)\right)={ }_{0}^{R_{n}} X_{i, t}(x) d x$ for $i=c$ and $G\left(X_{i, t}(x)\right)={ }_{n}^{R_{1}} X_{i, t}(x) d x$ for $\mathrm{i}=\mathrm{p}$.

Thus, replacing the dem and functions of foreign and hom e goods (consum ption and investm ent), we finally obtain the hom e final goods m arket equilibrium :

$$
\begin{aligned}
& Y_{c, t} / \quad P_{c, t}^{P}=1-\alpha_{c}^{C} \quad P_{c, t} / P_{c, t}^{c}-\mu C_{c, t}+1-\alpha_{c}^{l} \quad P_{c, t} / P_{c, t}^{l}{ }^{-\mu} I_{c, t} \\
& +(1-n) / n \alpha_{p}^{C} P_{c, t} / P_{p, t}^{c}-\mu C_{p, t}+\alpha_{p}^{1} P_{c, t} / P_{p, t}^{1}{ }^{-\mu} I_{p, t} \\
& +a\left(u_{c, t}\right) K_{c, t-1}+g \bar{Y} \exp \left(\varepsilon_{c, t}^{G}\right)+A C_{c, t}^{D} \text {, }
\end{aligned}
$$

where $P_{i, t}=G\left(P_{i, t}(i) / P_{i, t}\right)^{-} P$ denotes the price dispersion term, which is induced by the assum ed nature of price stidkiness.

Conceming the corporate loan $m$ arket, recall that entrepreneurs borrow to dom estic and foreign banks w ith varieties $\mathrm{b}$ produced by liquid illiquid banks, leading to the follow ing equilibrium for each country:

$$
\begin{aligned}
\mathrm{L}_{\mathrm{c}, \mathrm{t}}^{\mathrm{s}} / \mathrm{c}_{\mathrm{c}, \mathrm{t}}^{\mathrm{L}} & =1-\mathrm{\alpha}_{\mathrm{c}}^{\mathrm{L}} \quad\left(1+\mathrm{R}_{\mathrm{c}, \mathrm{t}}^{\mathrm{L}}\right) /\left(1+\mathrm{P}_{\mathrm{c}, \mathrm{t}}^{\mathrm{L}}\right)^{-\mathrm{v}} \mathrm{L}_{\mathrm{c}, \mathrm{t}} \\
& +\mathrm{n} /(1-\mathrm{n}) \mathrm{\alpha}_{\mathrm{p}}^{\mathrm{L}}\left(1+\mathrm{R}_{\mathrm{c}, \mathrm{t}}^{\mathrm{L}}\right) /\left(1+\mathrm{P}_{\mathrm{p}, \mathrm{t}}^{\mathrm{L}}\right)^{-\mathrm{v}} \mathrm{L}_{\mathrm{p}, \mathrm{t}}
\end{aligned}
$$

where $\underset{i, t}{L}$ is the credit rate dispersion term . 
Tuming to the interbank $m$ arket, the perfect com petition involves no interest rate dispersion betw een loan varieties. It clears when the follow ing condition betw een liquid banks and hom e and foreign illiquid banks holds:

$$
\begin{aligned}
I B_{c, t}^{\mathrm{s}}(1-\lambda) / \lambda & =1-\alpha_{c}^{l B} \quad\left(1+R_{c, t}^{\mid B}\right) /\left(1+P_{c, t}^{l B}\right)^{-\xi} \mid B_{c, t}^{d} \\
& +n /(1-n) \alpha_{p}^{l B}\left(1+R_{c, t}^{l B}\right) /\left(1+P_{p, t}^{l B}\right)^{-\xi} I B_{p, t}^{d}
\end{aligned}
$$

$\mathrm{R}$ eferences

Abo-Zaid, S., 2015. Optimal monet ary policy with the cost channel and monopolistically-competitive banks. Journal of Macroeconomics 45, 284-299.

Adam, K., 2011. Government debt and optimal monetary and fiscal policy. European Economic Review 55 (1), 57-74.

Adjemian, S., Bastani, H., Juillard, M., Mihoubi, F., Perendia, G., Ratto, M., Villemot, S., 2011. Dynare: Reference manual, version 4. Dynare Working Papers.

Angelini, P., Neri, S., Panetta, F., 2014. The interaction between capital requirements and monetary policy. Journal of Money, Credit and Banking 46 (6), 1073-1112.

Baltensperger, E., 1980. Alternative approaches to the theory of the banking firm. Journal of monetary economics 6 (1), 1-37.

Basel III accords, 2010. Basel 111: A global regulatory framework for more resilient banks and banking systems.

Beck, T., et al., 2016, Regulatory cooperation on cross-border banking - progress and challenges after the crisis. National Institute Economic Review 235 (1).

Bernanke, B., Gertler, M., Gilchrist, S., 1999. The financial accelerator in a quantitative business cycle framework. Handbook of macroeconomics 1, 1341-1393.

Brooks, S. P., Gelman, A., 1998. General methods for monitoring convergence of iterative simulations Journal of computational and graphical statistics 7 (4), 434-455.

Brunnermeier, M., De Gregorio, J., Eichengreen, B., El-Erian, M., Fraga, A., Ito, T., Lane, P., PisaniFerry, J., Prasad, E., Rajan, R., et al., 2012. Banks and cross-border capital flows: Policy challenges and regulatory responses. Brookings Committee on International Economic Policy and Reform , 1-45. 
Brzoza-Brzezina, M., Kolasa, M., Makarski, K., 2015. Monetary and macroprudential policy with foreign currency loans (1783).

Carboni, G., Darracq Paries, M., Kok Sorensen, C., 2013. Exploring the nexus between macro-prudential policies and monetary policy measures: Evidence from an estimated DSGE model for the euro area. Becker Friedman Institute for Research in Economics Working Paper (2013-005).

Cecchetti, S. G., Tucker, P. M., 2016. Is there macroprudential policy without international cooperation? CEPR Discussion Paper DP11042, Centre for Economic Policy Research.

Christiano, L. J., Eichenbaum, M., Evans, C. L., 2005. Nominal rigidities and the dynamic effects of a shock to monetary policy. Journal of political Economy 113 (1), 1-45.

Clerc, L., Derviz, A., Mendicino, C., Moyen, S., Nikolov, K., Stracca, L., Suarez, J., Vardoulakish, A. P., 2015. Capital regulation in a macroeconomic model with three layers of default. International Journal of Central Banking.

Cosimano, T. F., 1987. The federal funds market under bank deregulation. Journal of Money, Credit and Banking 19 (3), 326-339.

Cosimano, T. F., 1988. The banking industry under uncertain monetary policy. Journal of banking \& finance 12 (1), 117-139.

Cosimano, T. F., Van Huyck, J. B., 1989. Dynamic monetary control and int erest rate stabilization. Journal of Monetary Economics 23 (1), 53-63.

Curdia, V., Woodford, M., 2011. The central-bank balance sheet as an instrument of monetary policy. Journal of Monetary Economics 58 (1), 54-79.

Darracq-Pariès, M., Kok-Sørensen, C., Rodriguez-Palenzuela, D., 2011. Macroeconomic propagation under different regulatory regimes: Evidence from an estimated dsge model for the euro area. International Journal of Central Banking 7 (4), 49-113.

Dawson, C., Henley, A., 2013. Over-optimism and entry and exit from self-employment. International Small Business Journal 31 (8), 938-954

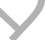

Dedola, L., Lombardo, G., 2012. Financial frictions, financial integration and the international propagation of shocks. Economic Policy 27 (70), 319-359.

Dermine, J., De Carvalho, C. N., 2006. Bank loan losses-given-default: A case study. Journal of Banking \& Finance 30 (4), 1219-1243 
Diamond, D. W., Rajan, R. G., 2001. Banks, short-term debt and financial crises: theory, policy implications and applications. In: Carnegie-Rochester Conference Series on Public Policy. Vol. 54. Elsevier, pp. $37-71$.

Elyasiani, E., Kopecky, K. J., Van Hoose, D., 1995. Costs of adjustment, portfolio separation, and the dynamic behavior of bank loans and deposits. Journal of Money, Credit and Banking 27 (4), 955-974.

ESRB handbook, 2014. The esrb handbook on operationalising macro-prudential policy in the banking sector.

Fahr, S., Zochowski, D., 2015. Financial stability review, may. URL https://www.ecb.europa.eu/pub/fsr/shared/pdf/sfafinancialstabilittyreview201505. en.pdf

Finger, K., Lux, T., et al., 2014. Friendship between banks: An application of an actor-oriented model of network formation on interbank credit relations. Tech. rep., Kiel Working Paper.

Flannery, M. J., 1982. Retail bank deposits as quasi-fixed factors of production. The American Economic Review 72 (3), 527-536.

Fraisse, H., Lé, M., Thesmar, D., 2013. The real effects of bank capital requirements. Débats économiques et financiers 8, 3-26.

Freixas, X., Rochet, J.-C., 2008. Microeconomics of banking. MIT Press Books 1.

French, K. R., Poterba, J. M., 1991. Investor diversification and international equity markets. The American Economic Review 81 (2), 222-226.

Fricke, D., Lux, T., 2015. Core-periphery structure in the overnight money market: evidence from the e-mid trading platform. Computational Economics 45 (3), 359-395.

Galí, J., 2013. Notes for a new guide to keynes (i): wages, aggregate demand, and employment. Journal of the European Economic Association 11 (5), 973-1003.

$$
\text { . }
$$

Garcia-de Andoain, C., Hoffmann, P., Manganelli, S., 2014. Fragmentation in the euro overnight unsecured money market. Economics Letters 125 (2), 298-302.

Gerali, A., Neri, S., Sessa, L., Signoretti, F. M., 2010. Credit and banking in a dsge model of the euro area. Journal of Money, Credit and Banking 42 (s1), 107-141.

Giannone, D., Lenza, M., Pill, H., Reichlin, L., 2012. The ecb and the interbank market. The Economic Journal $122(564)$. 
Gilchrist, S., Ortiz, A., Zakrajsek, E., 2009. Credit risk and themacroeconomy: Evidencefrom an estimated dsge model. Unpublished manuscript, Boston University .

Helpman, E., Melitz, M. J., Yeaple, S. R., 2004. Export versus FDI with heterogeneous firms. The American Economic Review 94 (1), 300-316.

lacoviello, M., 2015. Financial business cycles. Review of Economic Dynamics 18 (1), 140-163.

Jeanne, O., 2014. Macroprudential policies in a global perspective. Tech. rep., National Bureau of Economic Research.

Jeanne, O., Korinek, A., 2010. Excessive volatility in capital flows: A pigouvian taxation approach. Tech. rep., National Bureau of Economic Research.

Jeanne, O., Korinek, A., 2013. Macroprudential regulation versus mopping up after the crash. Tech. rep., National Bureau of Economic Research.

Jondeau, E., Sahuc, J.-G., de France, B., 2006. Optimal monetary policy in an estimated DSGE model of the euro area with cross-country heterogeneity. Banque de France.

Kolasa, M., 2009. Structural heterogeneity or asymmetric shocks? poland and the Euro area through the lens of a two-country DSGE model. Economic Modelling 26 (6), 1245-1269.

Kollmann, R., Enders, Z., Müller, G. J., 2011. Global banking and international business cycles. European Economic Review 55 (3), 407-426.

Kopecky, K. J., Van Hoose, D. D., 2012. Imperfect competition in bank retail markets, deposit and loan rate dynamics, and incomplete pass through. Journal of Money, Credit and Banking 44 (6), 1185-1205.

Landier, A., Thesmar, D., 2009. Financial contracting with optimistic entrepreneurs. Review of financial studies 22 (1), $117-150$.

Leeper, E. M., 1991. Equilibria under active and passive monetary and fiscal policies. Journal of monetary Economics 27 (1), 129-147.

Meh, C. A., Moran, K., 2010. The role of bank capital in the propagation of shocks. Journal of Economic Dynamics and Control 34 (3), 555-576.

Nier, E., Osinski, J., 2013. Key aspects of macroprudential policy. IMF Policy Paper .

Pérignon, C., Thesmar, D., Vuillemey, G., 2017. Wholesale funding dry-ups. Review of Finance 
Poutineau, J.-C., Vermandel, G., 2015. Cross-border banking flows spillovers in the Eurozone: Evidence from an estimated DSGE model. Journal of Economic Dynamics and Control 51, 378-403.

Puri, M., Robinson, D. T., 2013. The economic psychology of entrepreneurship and family business. Journal of Economics \& Management Strategy 22 (2), 423-444.

Quint, D., Rabanal, P., 2014. Monetary and macroprudential policy in an estimated DSGE model of the Euro area. International Journal of Central Banking 37, 169-236.

Reinhardt, D., Sowerbutts, R., 2015. Regulatory arbitrage in action: evidence from banking flows and macroprudential policy. Bank of England Staff Working Paper 546.

Rey, H., 2015. Dilemma not trilemma: the global financial cycle and monetary policy independence. Tech. rep., National Bureau of Economic Research.

Santomero, A. M., 1984. Modeling the banking firm: A survey. Journal of money, credit and banking 16 (4) $576-602$.

Schmitt-Grohé, S., Uribe, M., 2003. Closing small open economy models. Journal of international Economics 61 (1), 163-185.

Schmitt-Grohé, S., Uribe, M., 2007. Optimal simple and implementable monetary and fiscal rules. Journal of monetary Economics 54 (6), 1702-1725.

Sealey, C., 1985. Portfolio separation for stockholder owned depository financial intermediaries. Journal of Banking \& Finance 9 (4), 477-490.

Sealey, C. W., Lindley, J. T., 1977. Inputs, outputs, and a theory of production and cost at depository financial institutions. The journal of finance 32 (4), 1251-1266.

Smets, F., Wouters, R., 2003. An estimated dynamic stochastic general equilibrium model of the euro area. Journal of the European Economic Association 1 (5), 1123-1175.

Smets, F., Wouters, R., 2007. Shocks and frictions in us business cycles: A bayesian DSGE approach. American Economic Review 97 (3), 586-606.

Van den Heuvel, S. J., 2008. The welfare cost of bank capital requirements. Journal of Monetary Economics 55 (2), 298-320.

Van Leuvensteijn, M., Sørensen, C. K., Bikker, J. A., Van Rixtel, A. A., 2013. Impact of bank competition on the interest rate pass-through in the euro area. Applied Economics 45 (11), 1359-1380. 
VanHoose, D., 2009. The industrial organization of banking: bank behavior, market structure, and regulation. Springer Science \& Business Media.

Woodford, M., 2003. Interest and prices: Foundations of a theory of monetary policy. princeton university press.

Woodford, M., 2012. Inflation targeting and financial stability. Tech. rep., National Bureau of Economic Research.
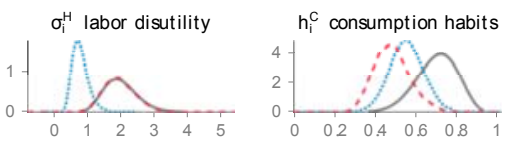

ki premium elasticity<smiles>C1C2C3C4C1C1C2C3C41</smiles>

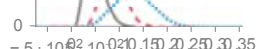

$\xi_{\mathrm{i}}^{\mathrm{W}}$ price indexation

$5-1 ;$

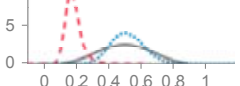

$\mathrm{h}_{\mathrm{i}}^{\mathrm{B}}$ bank loan habits

$4-\therefore$
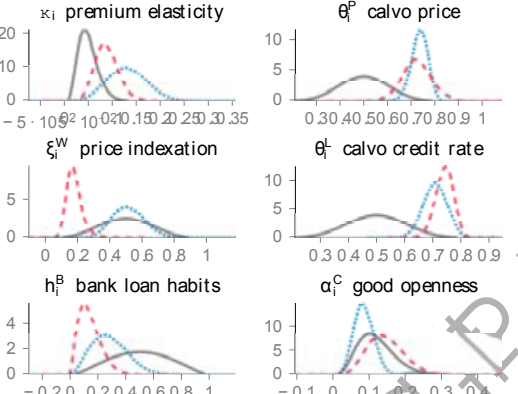

$\alpha_{i}^{c}$ good openness

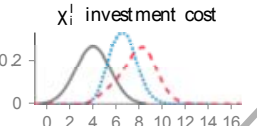

$\xi_{i}^{\mathrm{P}}$ price indexation
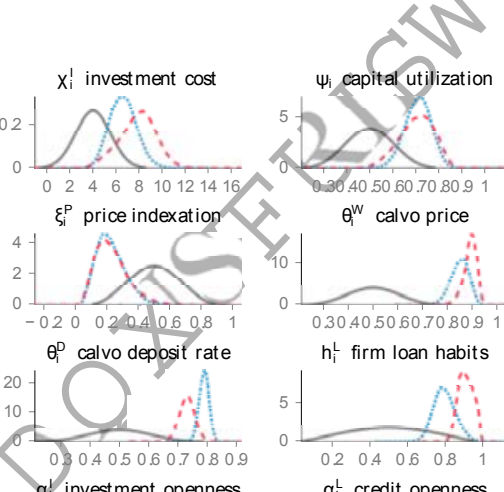

$\theta_{1}^{\mathrm{w}}$ calvo price

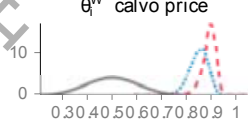

$h^{L}$ firm loan habits

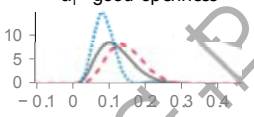

al investment openness
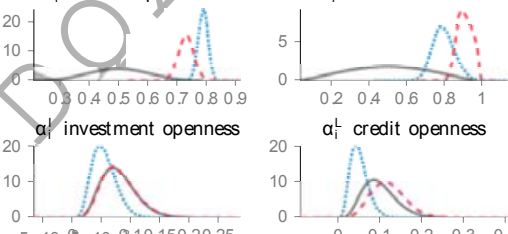

L

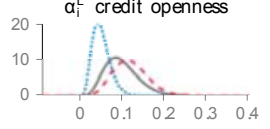

$\mu$ home/f. good subst.

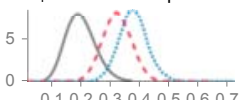

$1<\times<1$
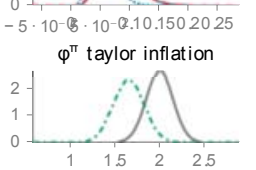

$\varphi^{\Delta y}$ taylor gdp growth

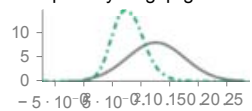

$\rho$ taylor smoothing $\theta_{1}^{E}$ employment elasticity
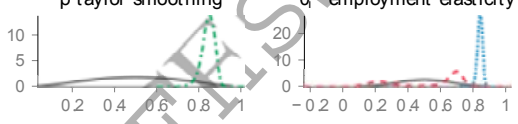

- Prior

- =-m... Posterior Core

- - - Posterior Periphery

..... Posterior Euro Area

Figure B.6: Prior and posterior distributions of structural parameters 
Table B.7

Prior and Posterior distributions of structural parameters and shock processes.

\begin{tabular}{|c|c|c|c|c|c|c|c|c|}
\hline \multicolumn{2}{|r|}{ Parameter } & \multirow{2}{*}{$\begin{array}{l}\text { Prior distributions } \\
\text { Shape[mean;std] }\end{array}$} & \multicolumn{6}{|c|}{ Posterior distribution [5\%:95\%] } \\
\hline & & & & CORE & & RIPHERY & & EURO \\
\hline \multicolumn{9}{|c|}{ shock st andar d deviat ions } \\
\hline$\sigma_{i}^{A}$ & Productivity & I G[0.10,2.00] & 0.82 & {$[0.64: 1.00]$} & 0.79 & [0.43:1.11] & & - \\
\hline$\sigma_{i}^{G}$ & Government spending & I G $[0.10,2.00]$ & 1.43 & [1.20:1.65] & 1.39 & [1.15:1.63] & & - \\
\hline$\sigma_{i}^{u}$ & Preferences & $\mathrm{I}[0.10,2.00]$ & 1.24 & {$[0.76: 1.73]$} & 1.52 & [0.98:2.06] & & - \\
\hline$\sigma_{1}^{1}$ & Investment costs & I G $[0.10,2.00]$ & 2.55 & [1.83:3.26] & 2.57 & {$[1.78: 3.47]$} & & - \\
\hline$\sigma_{i}^{p}$ & Firms markup & I G $[0.10,2.00]$ & 0.10 & {$[0.06: 0.14]$} & 0.29 & {$[0.17: 0.41]$} & & - \\
\hline$\sigma_{i}^{W}$ & Unions markup & I G $[0.10,2.00]$ & 0.45 & {$[0.33: 0.57]$} & 0.71 & {$[0.58: 0.85]$} & & - \\
\hline$\sigma_{i}^{N}$ & Firms net wealth & I G $[0.10,2.00]$ & 0.36 & {$[0.28: 0.45]$} & 0.37 & {$[0.26: 0.47]$} & & - \\
\hline$\sigma_{b}^{b}$ & Deposit markdown & $\mathrm{G}[0.10,2.00]$ & 0.30 & {$[0.23: 0.37]$} & 0.64 & {$[0.48: 0.79]$} & & - \\
\hline$\sigma_{1}^{B}$ & Bank liabilities & I $\mathrm{G}[0.10,2.00]$ & 5.89 & [4.63:7.10] & 9.75 & [7.95:11.57] & & - \\
\hline$\sigma_{i}^{L}$ & Credit markup & I G $[0.10,2.00]$ & 2.31 & [1.78:2.81] & 2.09 & {$[1.61: 2.57]$} & & - \\
\hline$\sigma^{R}$ & Monetary policy & I $\mathrm{G}[0.10,2.00]$ & & - & & & 0.09 & [0.07:0.10] \\
\hline \multicolumn{9}{|c|}{ shock process ar (1) } \\
\hline$\rho_{i}^{A}$ & Productivity & $\mathrm{B}[0.50,0.20]$ & 0.98 & {$[0.97: 0.99]$} & 0.96 & [0.91:1.00] & & - \\
\hline$\rho_{i}^{G}$ & Government spending & $\mathrm{B}[0.50,0.20]$ & 0.87 & [0.82:0.93] & 0.63 & [0.44:0.82] & & - \\
\hline$\rho_{i}^{u}$ & Preferences & $\mathrm{B}[0.50,0.20]$ & 0.29 & {$[0.08: 0.49]$} & 0.82 & {$[0.67: 0.96]$} & & - \\
\hline$\rho_{i}^{1}$ & Investment costs & $\mathrm{B}[0.50,0.20]$ & 0.79 & {$[0.70: 0.88]$} & 0.68 & {$[0.50: 0.90]$} & & - \\
\hline$\rho_{i}^{p}$ & Firms markup & $\mathrm{B}[0.50,0.20]$ & 0.99 & [0.99:1.00] & 0.76 & [0.54:0.95] & & - \\
\hline$\rho_{i}^{w}$ & Unions markup & $\mathrm{B}[0.50,0.20]$ & 0.49 & {$[0.21: 0.77]$} & 0.16 & [0.02:0.30] & & - \\
\hline$\rho_{i}^{N}$ & Firms net wealth & $\mathrm{B}[0.50,0.20]$ & 0.86 & [0.81:0.90] & 0.91 & [0.87:0.95] & & - \\
\hline$\rho_{\mathrm{b}}^{\mathrm{b}}$ & Deposit markdown & $\mathrm{B}[0.50,0.20]$ & 0.88 & [0.84:0.93] & 0.90 & {$[0.84: 0.95]$} & & - \\
\hline$\rho_{i}^{B}$ & Bank liabilities & $\mathrm{B}[0.50,0.20]$ & 0.94 & {$[0.90: 0.99]$} & 0.96 & [0.93:0.99] & & - \\
\hline$\rho_{i}^{L}$ & Credit markup & $\mathrm{B}[0.50,0.20]$ & & [0.55:0.86] & 0.68 & [0.54:0.82] & & - \\
\hline$\rho^{k}$ & Monetary policy & $\mathrm{B}[0.50,0.20]$ & & - & & - & 0.36 & [0.25:0.48] \\
\hline \multicolumn{9}{|c|}{ int er nat ional shock cor rel at ion } \\
\hline $\operatorname{cor} r_{t}^{A}$ & Productivity & $\mathrm{N}[0.20,0.20]$ & & - & & - & 0.20 & {$[0.01: 0.40]$} \\
\hline $\operatorname{cor} r_{t}^{t}$ & Government spending & $\mathrm{N}[0.20,0.20]$ & & - & & - & 0.13 & {$[-0.06: 0.33]$} \\
\hline corr $r_{t}^{u}$ & Preferences & $N[0.20,0.20]$ & & - & & - & 0.07 & {$[-0.12: 0.26]$} \\
\hline corr $r_{t}^{t}$ & Investment costs & $\mathrm{N}[0.20,0.20]$ & & - & & - & 0.45 & {$[0.28: 0.63]$} \\
\hline corr $r_{t}^{p}$ & Firms markup & $N[0.20,0.20]$ & & - & & - & 0.28 & {$[0.10: 0.47]$} \\
\hline corr $r_{t}^{W}$ & Unions markup & $\mathrm{N}[0.20,0.20]$ & & - & & - & 0.24 & {$[0.08: 0.42]$} \\
\hline $\operatorname{corr}_{t}^{N}$ & Firms net wealth & $\mathrm{N}[0.20,0.20]$ & & - & & - & 0.33 & {$[0.15: 0.51]$} \\
\hline corr $r_{t}^{D}$ & Deposit markdown & $N[0.20,0.20]$ & & - & & - & 0.68 & [0.56:0.81] \\
\hline $\operatorname{cor} r_{t}^{B}$ & Bank liabilities & $0,0.20]$ & & - & & - & 0.00 & [-0.21:0.22] \\
\hline $\operatorname{corr} r_{t}^{L}$ & Credit markup & $N[0.20,0.20]$ & & - & & - & 0.81 & {$[0.72: 0.90]$} \\
\hline \multicolumn{9}{|c|}{ st ruct ur al par amet er s } \\
\hline$\sigma_{i}^{\mathrm{H}}$ & Labour disutility & $\mathrm{G}[2.00,0.50]$ & 0.79 & {$[0.41: 1.15]$} & 1.96 & {$[1.17: 2.73]$} & & - \\
\hline$h_{h}^{c}$ & Consumption ha & $\mathrm{B}[0.70,0.10]$ & 0.55 & [0.42:0.69] & 0.48 & [0.34:0.62] & & - \\
\hline$\theta^{p}$ & Calvo price & $\mathrm{B}[0.50,0.10]$ & 0.72 & {$[0.67: 0.78]$} & 0.72 & [0.62:0.82] & & - \\
\hline$\xi_{i}^{p}$ & Price indexation & $\mathrm{B}[0.50,0.15]$ & 0.22 & {$[0.08: 0.37]$} & 0.23 & {$[0.07: 0.38]$} & & - \\
\hline$\theta_{i}^{w}$ & Calvo wage & $\mathrm{B}[0.50,0.10]$ & 0.85 & [0.79:0.91] & 0.89 & [0.85:0.93] & & - \\
\hline$\xi_{i}^{W}$ & Wage indexation & $\mathrm{B}[0.50,0.15]$ & 0.51 & {$[0.35: 0.67]$} & 0.18 & {$[0.10: 0.25]$} & & - \\
\hline$\theta_{i}^{E}$ & Employment elasticity & $\mathrm{B}[0.50,0.10]$ & 0.84 & {$[0.81: 0.86]$} & 0.52 & {$[0.18: 0.74]$} & & - \\
\hline$\theta_{L}^{L}$ & Calvo credit rate & $\mathrm{B}[0.50,0.10]$ & 0.71 & [0.64:0.78] & 0.74 & [0.69:0.79] & & - \\
\hline$\theta_{i}^{b}$ & Calvo deposit rate & $\mathrm{B}[0.50,0.10]$ & 0.79 & {$[0.76: 0.81]$} & 0.73 & [0.69:0.77] & & - \\
\hline$x !$ & Investment costs & $N[0.50,1.50]$ & 6.59 & [4.63:8.41] & 7.83 & [5.08:10.3] & & - \\
\hline & Utifization elasticity & $\mathrm{B}[0.50,0.10]$ & 0.71 & {$[0.62: 0.80]$} & 0.70 & {$[0.58: 0.82]$} & & - \\
\hline & External finance elasticity & $\mathrm{B}[0.05,0.02]$ & 0.13 & [0.06:0.19] & 0.09 & [0.05:0.13] & & - \\
\hline & Loan demand habits & $\mathrm{B}[0.50,0.20]$ & 0.79 & [0.70:0.89] & 0.91 & {$[0.85: 0.97]$} & & - \\
\hline$h_{i}^{B}$ & Interbank habits & $\mathrm{B}[0.50,0.20]$ & 0.28 & [0.07:0.48] & 0.14 & {$[0.02: 0.26]$} & & - \\
\hline$\alpha_{i}^{c}$ & Goods market openness & $\mathrm{B}[0.12,0.05]$ & 0.08 & {$[0.04: 0.13]$} & 0.14 & {$[0.07: 0.22]$} & & - \\
\hline$a_{j}^{!}$ & Inv. market openness & $\mathrm{B}[0.08,0.03]$ & 0.05 & [0.02:0.09] & 0.08 & [0.03:0.13] & & - \\
\hline$\alpha_{L}^{L}$ & Credit market openness & $\mathrm{B}[0.10,0.04]$ & 0.05 & {$[0.02: 0.08]$} & 0.12 & {$[0.05: 0.18]$} & & - \\
\hline$\alpha_{i}^{B}$ & Interbank openness & $\mathrm{B}[0.20,0.05]$ & 0.38 & {$[0.30: 0.46]$} & 0.32 & {$[0.24: 0.4]$} & & - \\
\hline$\mu$ & Substitutability goods & $G[1.50,0.50]$ & & - & & - & 1.42 & [0.99:1.83] \\
\hline$\rho$ & MPR smoothing & $\mathrm{B}[0.50,0.20]$ & & - & & - & 0.84 & {$[0.80: 0.89]$} \\
\hline$\varphi^{\pi}$ & MPR inflation & $N[2.00,0.15]$ & & - & & - & 1.65 & [1.37:1.92] \\
\hline$\varphi^{\Delta y}$ & MPR GDP growth & $N[0.12,0.05]$ & & - & & - & 0.08 & {$[0.03: 0.12]$} \\
\hline \multicolumn{3}{|c|}{ Marginal log-likelihood } & \multicolumn{6}{|c|}{-1199.2} \\
\hline
\end{tabular}

Not e: I G denotes the Inverse Gamma distribution, B the Betą, N the Normal, G the Gamma. 